\title{
Comparing the Investment Behavior of Public and Private Firms* ${ }^{*}$
}

\author{
John Asker \\ Stern School of Business \\ New York University \\ and NBER
}

\author{
Joan Farre-Mensa \\ Harvard Business School
}

Alexander Ljungqvist

Stern School of Business

New York University

and NBER

July 29, 2011

\footnotetext{
* We are grateful to Sageworks Inc. for access to their database on private companies, and to Drew White and Tim Keogh of Sageworks for their help and advice regarding their data. Thanks for helpful comments and suggestions go to Mary Billings, Jesse Edgerton, Alex Edmans, Yaniv Grinstein, David Hirshleifer, Hamid Mehran, Bruce Petersen, Joshua Rauh, Michael Schill, and Stanley Zin and to various seminar and conference audiences. We are grateful to Mary Billings for sharing her ERC data with us. Ljungqvist gratefully acknowledges generous financial support from the Ewing M. Kauffman Foundation under the Berkley-Kauffman Grant Program.

${ }^{\dagger}$ Address for correspondence: New York University, Stern School of Business, Suite 9-160, 44 West Fourth Street, New York NY 10012-1126. Phone 212-998-0304. Fax 212-995-4220. e-mail al75@nyu.edu.
} 


\title{
Comparing the Investment Behavior of Public and Private Firms
}

\begin{abstract}
We evaluate differences in investment behavior between stock market listed and privately held firms in the U.S. using a rich new data source on private firms. Listed firms invest less and are less responsive to changes in investment opportunities compared to observably similar, matched private firms, especially in industries in which stock prices are particularly sensitive to current earnings. These differences do not appear to be due to unobserved differences between public and private firms, how we measure investment opportunities, lifecycle differences, or our matching criteria. We suggest that the patterns we document are most consistent with theoretical models emphasizing the role of managerial myopia.
\end{abstract}

Key words: Corporate investment; $Q$ theory; Private companies; Managerial incentives; Agency costs; Short-termism; Managerial myopia; IPOs.

JEL classification: D22; D92; G31; G32; G34. 
This paper compares the investment behavior of stock market listed (or 'public') firms to that of observably similar privately held (or 'private') firms, using a novel panel dataset of private U.S. firms that contains data for around 250,000 firm-years over the period 2001-2007. Almost everything we know about corporate investment at the micro level is based on evidence from public firms, ${ }^{1}$ which number only a few thousand, yet private firms form a substantial part of the U.S. economy. ${ }^{2}$ We estimate that in 2007 , private U.S. firms accounted for $54.5 \%$ of aggregate non-residential fixed investment, $67.1 \%$ of privatesector employment, $57.6 \%$ of sales, and $20.6 \%$ of aggregate pre-tax profits. Nearly all of the 6 million U.S. firms are private (only $0.08 \%$ are listed), and many are small, but even among the larger firms, private firms predominate: Among those with 500 or more employees, for example, private firms accounted for $85.6 \%$ in $2007 .^{3}$

Our empirical tests unearth two intriguing new patterns. First, a nearest-neighbor matching estimator reveals that private firms invest substantially more than do public firms matched on size and industry. On average, private firms invest nearly $10 \%$ of total assets a year compared to only $4 \%$ among public firms. Second, private firms are 3.5 times more responsive to changes in investment opportunities than are public firms, based on standard investment regressions in the tradition of tests of the $Q$ theory of investment (see Hayashi (1982) or, more recently, Gomes (2001), Cummins, Hassett, and Oliner (2006), Bloom, Bond, and van Reenen (2007), or Bakke and Whited (2010)).

The difference in investment sensitivities does not appear to be driven by lifecycle effects, how we measure investment opportunities, or which characteristics we match on. In addition, we exploit a plausibly exogenous tax shock to sidestep the need to directly measure investment opportunities, which may be measured with error. This experiment reveals that private firms respond strongly to changes in investment opportunities whereas public firms barely respond at all. In another alternative identification

\footnotetext{
${ }^{1}$ Most studies of investment dynamics use firm-level data from Compustat and so focus on public firms. The exceptions are studies that use plant-level data from the Census of Manufactures. Prominent examples include Caballero et al. (1995) and Cooper and Haltiwanger (2006). Plant-level studies do not examine the ownership structure of the plants' owners.

${ }^{2}$ Private firms should not be confused with venture capital-backed firms. The latter are a subset of the population of private firms, but they are few in number: Of the around 6 million private firms operating in the U.S. in 2007, only around 4,000 were funded by VCs. VC-backed firms come from a narrow set of industries and are not representative of private firms in general. ${ }^{3}$ The denominators in these estimates are from the National Income and Product Accounts (http://www.bea.gov/national) and the Statistics of U.S. Businesses (http://www.census.gov/econ/susb/data/susb2007.html). The numerators are based on CRSPCompustat data for U.S. corporations listed on a national exchange (the NYSE, AMEX, or Nasdaq).
} 
strategy, we exploit within-firm variation in listing status for a sample of firms that go public without raising new capital. This differences away any time-invariant firm-level unobservables. The identifying assumption of this test is that these firms go public purely in order to change their ownership structure (that is, the expressed intention was to allow existing owners to 'cash out'). The within-firm results show that IPO firms are significantly more sensitive to investment opportunities in the five years before they go public than after. Indeed, once they are public, their investment sensitivity becomes indistinguishable from that of observably similar, already-public firms.

What would cause public and private firms to invest so differently? A natural place to look for an answer is the agency literature. While stock markets provide investors with liquidity and opportunities for diversification, and thereby reduce firms' cost of capital (Pagano, Panetta, and Zingales (1998)), a stock market listing can have two detrimental effects. First, ownership and control must be at least partially separated, as shares are sold to outside investors who are not involved in managing the firm. This may lead to agency problems if managers' interests diverge from those of their investors (Berle and Means (1932), Jensen and Meckling (1976)). Second, liquidity makes it easy for shareholders to sell their stock at the first sign of trouble rather than actively monitoring management - a practice sometimes called the 'Wall Street walk.' This weakens incentives for effective corporate governance (Bhide (1993)). Private firms, in contrast, are often owner-managed and even when not, are both illiquid and typically have highly concentrated ownership, which encourages their owners to monitor management more closely. Indeed, evidence from the Federal Reserve's 2003 Survey of Small Business Finances (SSBF) shows that 94.1\% of the larger private firms in the survey have fewer than ten shareholders (most have fewer than three), and $83.2 \%$ are managed by the controlling shareholder. ${ }^{4,5}$ According to another survey, by Brau and Fawcett (2006), keeping it that way is the main motivation for staying private in the U.S. As a result, agency problems are likely to be greater among public firms than among private ones. ${ }^{6}$

There are three strands of the agency literature that argue investment will be suboptimal as a result.

\footnotetext{
${ }^{4}$ See Tables A7 and A8 in our Online Data Appendix at http://papers.ssrn.com/sol3/papers.cfm?abstract_id=1659926. This online appendix also provides an extensive overview of the private firm data used in this study.

${ }^{5}$ Contrast this with the fact that the average (median) public-firm CEO in our sample owns a mere $8.4 \%(1.6 \%)$ of his firm's equity, and the average (median) public firm has 23,772 $(1,082)$ shareholders.

${ }^{6}$ Clearly, agency considerations are not the only difference between public and private firms. Public firms are subject to myriad rules and regulations designed to protect investors which may slow down, and possibly distort, investment decisions.
} 
First, Baumol (1959), Jensen (1986), and Stulz (1990) argue that managers have a preference for scale which they satisfy by 'empire building.' Empire builders invest regardless of the state of their investment opportunities. This could explain the lower investment sensitivity we observe among public firms.

Second, Bertrand and Mullainathan (2003) argue the opposite: Managers may have a preference for the 'quiet life.' When poorly monitored, managers may avoid the costly effort involved in making investment decisions, leading to lower investment levels and, presumably, lower investment sensitivities.

Third, models of 'managerial myopia' or 'short-termism' argue that a focus on short-term profits may distort investment decisions from the first-best when a public-firm manager derives utility from both the firm's current stock price and its long-term value. Short-termism can lead to either too much or too little investment. Overinvestment results when the manager has better information about the high quality of his investment opportunities, which he signals by overinvesting (e.g., Bebchuk and Stole (1993)). Underinvestment results if investors do not know how much the firm should optimally invest (see Miller and Rock (1985), Narayanan (1985), Stein (1989), Shleifer and Vishny (1990), von Thadden (1995), and Holmström (1999)). Essentially, the manager underinvests to create the impression that the firm's current and future profitability is greater than it really is, hoping this will boost today's share price (Stein (1989)).

The fact that we find lower investment levels among public firms seems inconsistent with empire building. The quiet life argument and short-termism models that predict underinvestment, on the other hand, fit the empirical facts we document. To shed further light on what drives the observed investment differences between public and private firms, we explore how the difference in investment behavior between public and private firms varies with a parameter that plays a central role in short-termism models: The sensitivity of share prices to earnings news. As we explain in Section 4, under short-termism a public-firm manager has no incentive to underinvest if current earnings are uninformative about future earnings, in which case we expect no difference in investment behavior between public and private firms. But the more sensitive share prices are to earnings news, the greater is the incentive to distort investment and hence the greater should be the difference between public and private firms' investment sensitivities.

These predictions can be tested using what the accounting literature calls 'earnings response coefficients' or ERC (Ball and Brown (1968)). For industries in which share prices are unresponsive to 
earnings news $(\mathrm{ERC}=0)$, we find no significant difference in investment sensitivities between public and private firms. As ERC increases, public firms' investment sensitivity decreases significantly while that of private firms remains unchanged. In other words, the difference in investment sensitivities between public and private firms increases in ERC, and this increase is driven by a change in public-firm behavior.

These cross-sectional patterns are consistent with the notion that public firms invest myopically. If that is true, we should find systematic differences in the share of public firms across industries. Specifically, if investment distortions increase in the informativeness of current earnings, as our crosssectional tests suggest, fewer firms should wish to be stock market listed in high-ERC industries than in low-ERC industries, all else equal. We test this prediction by regressing the share of public firms in an industry on the industry's ERC, controlling for other drivers of the listing decision. The results confirm that there are significantly fewer stock market listed firms in high-ERC industries. To illustrate, a onestandard deviation increase in ERC is associated with a decrease of a third in the share of public firms in an industry. These patterns are consistent with the interpretation that firms and investors view agencyinduced investment distortions, brought about by managerial myopia, as a cost of being publicly listed.

Our paper makes three contributions. First, we document economically important differences in the investment behavior of private and public firms. Because few private firms have an obligation to disclose their financials, relatively little is known about how private firms invest. Our comparison focuses on the segments of public and private firms that overlap in size and industry, so we essentially compare large private firms and smaller public firms. This is unlikely to skew our findings. Contemporaneous work shows that investment rates decrease significantly with size among public U.S. firms (see Gala and Julio (2011)), so the smaller public firms that end up in our sample are in fact the more active investors.

Second, we provide rare direct evidence of an important potential cost of a stock market listing by documenting that the investment of public firms in our sample appears to be distorted relative to that of comparable private firms. Calling it a distortion assumes that private firms, carefully screened to be observably similar, provide a good benchmark for how public firms would behave were their ownership and control more closely aligned. The data support this assumption.

Third, our analysis suggests that agency problems in public firms, and in particular short-termism, are 
an important driver of these differences. This finding adds to existing survey evidence of widespread short-termism in the U.S. Poterba and Summers (1995) find that public-firm managers prefer investment projects with shorter time horizons in the belief that stock market investors fail to properly value longterm projects. Ten years on, Graham, Harvey, and Rajgopal (2005, p. 3) report the startling survey finding that "the majority of managers would avoid initiating a positive NPV project if it meant falling short of the current quarter's consensus earnings [forecast]." This is not to say that effective corporate governance cannot reduce public-firm managers' focus on short-term objectives. Tirole (2001) argues that large shareholders have an incentive to actively monitor managers and fire them if necessary, while Edmans' (2010) model shows that the presence of large shareholders can reduce managerial myopia. But it is an empirical question whether these mechanisms are sufficiently effective on average. Our evidence suggests that, at least on the dimension of investment, this may not be the case.

The paper proceeds as follows. Section 1 briefly reviews related literature. Section 2 introduces a rich new database of private U.S. firms created by Sageworks Inc. (The Online Data Appendix describes it in detail.) Section 3 establishes our main empirical results, that public firms invest less and are less responsive to changes in investment opportunities than private firms. Section 4 investigates possible agency explanations for these findings. Section 5 concludes.

\section{Related Literature}

There is a small but growing empirical literature contrasting public and private firms. Using data for the population of British firms, Saunders and Steffen (2009) show that private firms face higher borrowing costs than do public firms; Michaely and Roberts (2007) show that private firms smooth dividends less than public firms; and Brav (2009) shows that private firms rely mostly on debt financing.

Before Sageworks became available, studies of private U.S. firms relied on limited samples. Gao, Lemmon, and $\mathrm{Li}$ (2010) compare CEO compensation in public and private firms in the CapitalIQ database, finding that public-firm pay - but not private-firm pay - is sensitive to measureable performance variables such as stock prices and profitability. When a firm goes public, pay becomes more performance-sensitive. Since the point of an incentive contract is to overcome an agency problem, these patterns are consistent with survey evidence showing that private firms are subject to fewer agency 
problems than public firms. Edgerton (2010) shows that public firms overuse corporate jets compared to observably similar private firms, while Sheen (2009) analyzes hand-collected investment data for public and private firms in the chemical industry, finding results similar to ours. Bharat, Dittmar, and Sivadasan (2010) analyze within-firm changes in productivity in a sample of U.S. manufacturing firms that are taken private, for example by a private equity fund. For this group of firms, productivity does not change after the change in ownership, relative to similar still-listed firms, and firms close down plants after being taken private. This is consistent with the widely held view that private equity buyers target firms in shrinking industries that are in need of consolidation and disinvestment.

The empirical literature on the effects of agency costs on investment, surveyed in Stein (2003), is vast. We depart from it by exploiting variation along the extensive (public/private) margin. Existing work in this area focuses instead on the intensive margin. For example, Wurgler (2000), Knyazeva et al. (2007), Franzoni (2009), Bøhren et al. (2009), Gopalan et al. (2010), and Xu (2011) relate investment among public firms to variation in corporate governance, while Fang, Tian, and Tice (2010) examine whether public firms with more liquid shares (and thus more footloose investors) are less innovative. Our approach is distinct from, but complementary to, this body of work.

Finally, the accounting literature documents that some public-firm managers sometimes act myopically, in the specific sense of taking costly actions to avoid negative earnings surprises. Bhojraj et al. (2009) show that firms that barely beat analysts' earnings forecasts myopically cut discretionary spending. This avoids the short-run stock price hit associated with missing earnings forecasts (Skinner and Sloan (2002)) but over longer horizons leads to underperformance. Roychowdhury (2006) finds that firms discount product prices to boost sales and thereby meet short-term earnings forecasts. Baber, Fairfield, and Haggard (1991) find that firms cut R\&D spending to avoid reporting losses, and Dechow and Sloan (1991) find that CEOs nearing retirement cut R\&D spending to increase earnings. Bushee (1998) shows that these tendencies are mitigated in the presence of high institutional ownership.

\section{Sample and Data}

According to the Census, there were $6,049,655$ firms in the U.S. in $2007 .^{7}$ The vast majority of these

\footnotetext{
${ }^{7}$ See http://www.census.gov/econ/susb/data/susb2007.html.
} 
are privately held (in 2007, there were only 4,584 U.S. firms with a listing on a U.S. exchange) and even among the very largest private firms, most express no desire to go public. ${ }^{8}$ Unless they have issued public bonds, private firms are not subject to public reporting requirements, so little is known about how they invest. Our study is only possible because a new database on private U.S. firms, created by Sageworks Inc. in cooperation with hundreds of accounting firms, has recently become available. We provide a comprehensive overview of the data, along with detailed summary statistics, in the Online Data Appendix. ${ }^{9}$ Sageworks is similar to Compustat, a standard database for public U.S. firms. Like Compustat, Sageworks contains accounting data from income statements and balance sheets along with basic demographic information such as NAICS industry codes and geographic location-except that Sageworks exclusively covers private firms. Unlike in Compustat, firm names are masked, though each firm has a unique identifier allowing us to construct a panel. The main drawback of anonymity for our purposes is that we cannot observe transitions from private to public status in the Sageworks database. We will later describe how we assemble a dataset of such transitions from other sources.

Sageworks obtains data not from the private firms themselves, which could raise selection concerns, but from a large number of accounting firms which input data for all their unlisted corporate clients directly into Sageworks' database. Selection thus operates at the level of the accounting firm and not of their clients. Sageworks co-operates with most of the largest national accounting firms as well as 100s of regional players, but with proportionately fewer of the many thousand local accountants who service the smallest firms in the U.S. As a result, the main selection effect is that firms in Sageworks are substantially larger than the small private businesses covered in the only other large-scale private-firm dataset, the Survey of Small Business Finances (SSBF). ${ }^{10}$ This selection may be problematic for some research questions but it is innocuous for our purposes as very small firms have no realistic chance of being public.

Sageworks started in 2000 with fiscal year 2001 being the first panel year. The growth of the database over time is detailed in Table A2 in the Online Data Appendix. We have data through fiscal year 2007

\footnotetext{
${ }^{8}$ In Brau and Fawcett's (2006) survey of large private firms, only $10.5 \%$ had considered going public.

${ }^{9}$ Available at http://papers.ssrn.com/sol3/papers.cfm?abstract_id=1659926.

${ }^{10}$ Unlike Sageworks, the SSBF is not a panel. Now discontinued, it surveyed a different cohort of firms in 1987, 1993, 1998, and 2003.
} 
and use 2001 to construct lags, giving a six-year panel covering 95,370 firms and 250,507 firm-years. ${ }^{11}$

\subsection{Sample Construction}

Full details of our sample construction can be found in Table A1 in the Online Data Appendix, along with further summary statistics describing the Sageworks database. To construct our sample of private firms, we exclude from Sageworks 10,104 Canadian firms as well as 3,930 firms with data quality problems (i.e., those violating basic accounting identities and firms with missing or negative total assets).

To be part of our public-firm sample, a firm has to be recorded in both Compustat and CRSP during our sample period; be incorporated in the U.S. and listed on a major U.S. exchange (NYSE, AMEX, or Nasdaq); have valid stock prices in CRSP; and have a CRSP share code of 10 or 11 (which screens out non-operating entities such as real estate investment trusts, mutual funds, or closed-end funds).

As is customary, we exclude financial firms (the NAICS equivalent to SIC 6) and regulated utilities (SIC 49) from both the public and private samples. Since our empirical models exploit within-firm variation, we exclude firms with fewer than two years of complete data. Both the public-firm and privatefirm samples cover the period from 2002 through 2007. The public-firm sample consists of 3,926 firms and 19,203 firm-years; the private-firm sample contains 32,204 firms and 88,568 firm-years.

\subsection{Matching}

In an ideal world, we would compare the investment behavior of two otherwise identical firms that differ only in their listing status. To get close to this ideal, we need to find pairs of public and private firms that are observably similar to each other. Matching is a convenient way to do so. Our preferred match is based on size and industry, the two dimensions in which the samples differ the most and which, economically, likely affect investment. ${ }^{12}$ Not surprisingly, Compustat firms are larger than Sageworks firms. The top graph in Figure 1 shows the distribution of total assets in log 2000 dollars for each dataset. The distributions overlap only to a limited extent. Table 1 shows that the mean (median) public firm has total assets of $\$ 1,364.4$ million (\$246.2 million), compared to $\$ 7.1$ million (\$1.3 million) for private firms. The industry distributions are also different; see Tables A3 and A15 in the Online Data Appendix.

\footnotetext{
${ }^{11}$ Sageworks is free of survivorship bias. If a firm goes public, dies, or switches to an accounting firm that doesn't co-operate with Sageworks, its data time series will end but all of its historical data remains in the database.

${ }^{12}$ A large body of work, surveyed in Jorgenson (1971), has documented cross-industry variation in investment, while Gala and Julio (2011) report evidence of an inverse relation between firm size and investment.
} 
Other variables also differ in the two samples, but size is by far the most important observable difference in our data. This can easily be seen in a probit model conditioned on a broad selection of firm characteristics and a set of year effects. We find that one standard deviation increases in these firm characteristics have the following effects on the probability that a sample firm is public: Log total real assets: +10.6 percentage points; cash holdings: +0.52 percentage points; return on assets (ROA): -0.46 percentage points; leverage: -0.17 percentage points; and sales growth: +0.09 percentage points. The unconditional probability is $17.8 \%$, so size is the only covariate that is economically significant. The pseudo- $R^{2}$ of $84.1 \%$ suggests there is little unexplained variation left that could be due to unobserved characteristics. We thus match on size and industry, though we will consider alternatives for robustness. Matching on size means that our matched sample consists of small public and large private firms.

In the language of the matching literature surveyed in Imbens and Wooldridge (2009), we use a nearest-neighbor match adapted to a panel setting. Starting in fiscal year 2002, for each public firm, we find the private firm that is closest in size and that operates in the same four-digit NAICS industry, ${ }^{13}$ requiring that the ratio of their total assets $(T A)$ is less than 2 (i.e., $\max \left(T A_{\text {public }}, T A_{\text {private }}\right) / \min \left(T A_{\text {public }}\right.$, $\left.T A_{\text {private }}\right)<2$ ). If no match can be found, we discard the observation and look for a new match for that firm in the following year. Once a match is formed, it is kept in subsequent years to ensure the panel structure of the data remains intact. (If a matching firm exits the panel, a new match is spliced in.) The resulting matched sample contains 4,975 public-firm-years and an equal number of private-firm-years. Because we match with replacement, to maximize the match rate and match quality, the matched sample contains 1,666 public firms and 620 private firms. Our results are not sensitive to matching without replacement. Standard errors are appropriately clustered to account for the resampling of private firms. ${ }^{14}$

How good is the match? The bottom graph in Figure 1 shows the distribution of log real assets for

\footnotetext{
${ }^{13}$ As we will show, our results are robust to using finer industry classifications, such as NAICS5 or NAICS6.

${ }^{14}$ We cluster standard errors in the usual way but do not adjust for variation introduced by the matching procedure. No such adjustment yet exists for matched panels, though subsampling is potentially a viable solution (see Abadie and Imbens (2008)). Econometric theory is silent on the optimal size of the subsample. For robustness, we have computed standard errors using a standard subsampling procedure (see Politis, Romano, and Wolf (1999)) for different sizes, looking for one that seems robust within a reasonable local interval and that gives results similar to standard asymptotic estimates wherever a specification involves no additional variation that is unaccounted for. A subsample size of $70 \%$ satisfies these criteria. The resulting subsampled standard errors support all inferences presented in the paper, except in Table 3, column 5, where the coefficient on "Investment opp. x public" has a subsampled $p$-value of $12 \%$.
} 
matched public and private firms. The overlap is near perfect and the sample moments are very close. Average total assets, for example, are $\$ 144.7$ million and $\$ 120.0$ million for public and private firms and the difference is not statistically significant. The distribution of the ratio of matched pairs' total assets (our matching criterion) is centered on 1 , with 461 of the 1,666 public firms matched to somewhat larger private firms and the remaining 1,205 firms matched to somewhat smaller ones. Thus, matched firms are of similar size and so have a plausible choice between being public or private. In fact, empirically, they share almost the same propensity to be public: The propensity scores (i.e., predicted probabilities) associated with our nearest-neighbor match average 0.205 for public firms and 0.193 for the private ones.

\subsection{Measures of Investment Opportunities}

The investment literature proxies for a firm's investment opportunities using either Tobin's $Q$ or sales growth. $Q$ is usually constructed as the ratio of the firm's market value to the book value of its assets, but since private firms are not traded on a stock exchange, their market value is not observed. We thus favor sales growth, which can be constructed at the firm level for any firm, whether public or private. Sales growth (the annual percentage increase in sales) has been widely used as a measure of investment opportunities. See, for example, Rozeff (1982), Lehn and Poulsen (1989), Martin (1996), Shin and Stulz (1998), Whited (2006), Billett, King, and Mauer (2007), and Acharya, Almeida, and Campello (2007).

For robustness purposes, we also explore two $Q$ measures. The simplest measure constructs an 'industry $Q$ ' from public-firm data and then applies that to all firms, public and private. We measure industry $Q$ for each four-digit NAICS industry and year as the size-weighted average $Q$ of all public firms in that industry. Alternatively, we can impute $Q$ at the firm level. Campello and Graham (2007) suggest regressing $Q$, for public firms, on four variables thought to be informative about a firm's marginal product of capital (sales growth, ROA, net income before extraordinary items, and book leverage). The resulting regression coefficients are then used to generate 'predicted $Q$ ' for each public and each private firm.

\subsection{Measures of Investment}

Firms can grow their assets by either building new capacity or buying another firm's existing assets. These are reflected in capital expenditures (CAPEX) and mergers and acquisitions (M\&A), respectively. Many studies of investment focus on CAPEX, but there are reasons to expect systematic differences in the 
relative importance of M\&A and CAPEX for public and private firms. Unlike public firms, private firms usually cannot pay for their acquisitions with stock so their overall investment is likely to involve relatively more CAPEX than that of public firms. Sageworks data do not allow us to distinguish between CAPEX and M\&A, so we cannot test this conjecture. But to avoid biases when we compare public and private firms' overall investment behavior, we will measure investment in a way that captures both CAPEX and M\&A. This can be done by modeling investment as the annual increase in fixed assets.

Our main investment measure is gross investment, defined as the annual increase in gross fixed assets scaled by beginning-of-year total assets. ${ }^{15} \mathrm{We}$ also model net investment, defined analogously using net fixed assets. The difference between the two is depreciation. To the extent that depreciation represents assets that need replacing due to wear and tear or obsolescence, gross investment better captures the firm's investment decisions. (For detailed definitions of these and all other variables, see Appendix A.)

\subsection{Other Firm Characteristics}

Table 1 also shows that private firms have higher profits, less cash, and more debt, even after we match on size and industry. While interesting in their own right, we will show that these differences in observable characteristics do not drive our results.

\section{Differences in Public and Private Firm Investment Behavior}

We begin our empirical investigation by documenting sizable differences in investment levels between private and public firms using our size-and-industry matched sample and a range of alternative samples that match on a wider choice of firm characteristics. We then document that public and private firms differ in their response to changes in their investment opportunities using standard investment regressions in the style of the $Q$-theory literature. We also show that these differences in investment levels and in investment sensitivities are robust to a range of economic and measurement concerns, including concerns that age or lifecycle effects may contaminate inference; differences in tax treatment and accounting choices; and differences in observable characteristics such as size, cash holdings, or debt.

A standard concern in investment regressions is that investment opportunities are measured with

\footnotetext{
${ }^{15}$ Another form of investment, $R \& D$, does not change fixed assets and so is not captured by gross investment. We cannot model investment in R\&D explicitly as Sageworks does not break out R\&D spending. We will, however, report evidence showing it is highly unlikely that our results are driven by this data limitation.
} 
error. To address this, we first estimate Arellano-Bond (1991) models and then explore a natural experiment that exogenously varies the return on investment and so sidesteps the need to directly measure investment opportunities. Both approaches confirm that public firms are much less responsive to changes in investment opportunities. Finally, we report a test that uses within-firm variation in listing status, using hand-collected data for firms that switch from private to public status without raising new capital (a particular form of IPO).

\subsection{Differences in Investment Levels: Baseline Results and Alternative Matches}

Table 2 compares public and private firms' investment levels. It shows that private firms invest significantly more than public firms on average. The differences are substantial. In the full samples, private firms increase their gross and net fixed assets by an average of $7.6 \%$ and $3.3 \%$ of total assets a year, compared to $4.5 \%$ and $2.2 \%$ for public firms. In our baseline size-and-industry matched sample, the average differences are 5.6 and 7.2 percentage points in favor of private firms, respectively. (The median differences are smaller, largely because neither the median public firm nor the median private firm invests much.) These patterns are robust to matching on finer industry codes: Using five-digit NAICS has virtually no effect on the difference in investment, while using six-digit NAICS increases the difference from 5.6 percentage points in favor of private firms to 9.5 percentage points. When we include other firm characteristics besides size and industry among the matching criteria, the difference shrinks somewhat but remains highly significant, both economically and statistically: When matched on size, NAICS4 industry, and sales growth, private firms invest $3.9 \%$ of assets more than public firms, and when additionally matched on ROA, cash holdings, and book leverage, the difference is 3 percentage points.

\subsection{Differences in Investment Levels: Robustness}

The final rows of Table 2 report results for three robustness tests. The first concerns potential lifecycle effects. Public firms might simply be older and more mature than private ones, and so may have reached that part of their lifecycle when investment naturally slows down. Unfortunately, we cannot control for age directly since neither Compustat nor Sageworks contains data on founding years. But the following indirect tests suggest differences in age cannot explain the gap in investment levels.

How old are public firms? According to Ljungqvist and Wilhelm (2003), the average (median) firm in 
the U.S. goes public aged 10 (6). In our baseline matched sample, the average (median) Compustat firm has been public for 11.9 (9.3) years in 2004. This suggests that the average (median) public firm in our matched sample is around 21.9 (15.3) years old in 2004. For comparison, the average (median) SSBF private firm is 18.2 (15) years old in 2004 (see the Online Data Appendix). Based on these back-of-theenvelope calculations, it is not obvious that private firms are systematically younger than public ones.

To investigate the potential effect of unobserved differences in age more formally, Table 2 splits public firms by time-since-IPO. We code a firm as 'young' if its time-since-IPO in its first panel year is less than the median in that calendar year, and as 'old' otherwise. ${ }^{16}$ We then match public firms in each subsample to private firms based on industry and size, as before. We do find some evidence that younger public firms invest more than older public firms on average (4.6\% vs. $3.2 \%$ of total assets), but both groups invest significantly less than private firms, whose investment levels average more than $9 \%$.

The final two robustness tests concern legal form and accounting choices. Our private-firm sample pools sole proprietorships, limited liability companies (LLCs), partnerships and limited liability partnerships (LLPs) as well as firms incorporated under Subchapters C or S of the Internal Revenue Code. (See Table A5 in the Online Data Appendix for further details.) These legal forms are taxed differently and it is possible that taxes affect investment. Virtually all public firms are C Corps. When we restrict the private firms to also be C Corps, we continue to find a large gap in investment levels, averaging 7.1 percentage points in favor of private firms. Finally, when we exclude private firms that use cash-basis (rather than accrual) accounting, the difference is 5 percentage points.

\subsection{Differences in Investment Sensitivity: Baseline Models and Alternative Matches}

Next, we investigate differences in public and private firms' sensitivity to changing investment opportunities. In Table 3, we estimate standard investment regressions of gross investment on investment opportunities. ${ }^{17}$ A long line of literature shows that standard proxies for investment opportunities are not, as neoclassical theory predicts, a sufficient statistic for investment, and that changes in net worth, measured as ROA, correlate positively with investment. A significant ROA effect is often interpreted as a

\footnotetext{
${ }^{16}$ This procedure will not produce two equal-sized subsamples unless the mortality rates of young and old firms are exactly the same, but it keeps the panel structure intact by ensuring that firms do not switch between the two subsamples.

${ }^{17}$ As we will show later, we obtain similar results using net investment instead. Also, as we will show, our results are robust to including R\&D spending, which is left out of gross investment.
} 
sign of financing constraints (Fazzari, Hubbard, and Petersen (1988)), though some disagree (Kaplan and Zingales (1997, 2000), Erickson and Whited (2000)). While we are agnostic about the debate surrounding its interpretation, we follow the literature by including ROA. Finally, we remove unobserved timeinvariant heterogeneity through firm fixed effects, and we include year effects. ${ }^{18}$

The results in column 1 of Table 3 suggest that public firms' investment decisions are significantly less sensitive to changes in investment opportunities. The coefficient estimate is 0.136 for private firms, 3.5 times greater than the $0.136-0.097=0.039$ coefficient estimate for public firms. The difference between these estimates is statistically significant at the $1 \%$ level. We also find that investment is sensitive to ROA for private firms and significantly less so among public firms. This may indicate that private firms are more financially constrained than public ones.

Columns 2 and 3 show that our results are robust to matching on finer industry codes. Using five-digit NAICS (rather than NAICS4 as in column 1) has no effect at all on the point estimates. Using six-digit NAICS naturally reduces the sample size considerably but again suggests that public firms have significantly lower investment sensitivities than do private ones. (In fact, the difference is $50 \%$ larger when we use NAICS6 in our match.) Our findings thus do not appear to be driven by an overly noisy industry match, so we continue to match on NAICS4 in the remainder of the paper.

Columns 4 and 5 expand the matching criteria. Column 4 matches on sales growth in addition to size and industry, while column 5 matches on size, industry, sales growth, ROA, cash holdings, and book leverage. The resulting matches are quite tight. In column 4, propensity scores average 0.251 for matched public firms and 0.246 for matched private firms; in column 5 , mean propensity scores are 0.256 for both groups. This confirms that our public and private firms are observably very similar. In both columns, public-firm investment continues to be substantially less sensitive to changes in investment opportunities, with point estimates of $-0.061(p<0.001)$ and $-0.048(p=0.032)$. Thus, the observed difference in investment sensitivities is unlikely to be an artifact of our matching choices.

Columns 6 and 7 show that our findings are robust to using industry $Q$ and predicted $Q$ as alternative proxies for investment opportunities. In light of this, and because sales growth is the methodologically

\footnotetext{
${ }^{18}$ Recall that all firms in Sageworks are unlisted and all firms in Compustat are listed. Thus, our fixed-effects specifications cannot include a public-firm indicator, though we can let the effect of investment opportunities or ROA vary by listing status.
} 
sounder proxy in our setting, we report results using only sales growth in the remainder of the paper. ${ }^{19}$

\subsection{Differences in Investment Sensitivity: Robustness}

The results in Table 3 suggest a wide gap in the investment sensitivities of public and private firms. We now consider a broad range of potential confounding factors in an effort to close this gap.

\subsubsection{Age and Lifecycle Effects}

While we found no evidence that differences in age can explain the difference in investment levels between public and private firms, they could generate differences in investment sensitivities. Jovanovic and Rousseau (2010) argue that younger firms face a relatively lower cost of adopting new technologies and so are more sensitive to changes in investment opportunities. If private firms were systematically younger than public firms, such lifecycle effects could confound our results. As before, we cannot control for age directly. However, the following indirect tests suggest age is not an important confound.

As in Table 2, we split public firms into 'young' and 'old' ones and then match each group to private firms based on size and industry. The spirit of the test is simple. If Sageworks firms are systematically younger than matched Compustat firms and if this confound drives our results, then we should find no difference in investment sensitivities once we restrict the Compustat sample to 'young' firms. As columns 1 and 2 of Table 4 show, we find a significantly lower investment sensitivity for public firms relative to private firms in both subsamples. In fact, the point estimates of the difference are nearly identical in size: -0.095 for old firms and -0.096 for young firms.

Another way to look at the possible age confound is to test if investment sensitivity does change with age, as the lifecycle hypothesis supposes. Column 3 restricts the sample to public firms and interacts investment opportunities with the log of one plus the firm's time-since-IPO. The coefficient estimate is 0.002 ( $p=0.863$ ) so investment sensitivity does not appear to vary with firm age in our sample period.

Overall, these tests suggest that it is unlikely that public and private firms invest differently simply because they are at different points in their lifecycles.

\subsubsection{The Omission of R\&D Spending in the Private Firm Data}

Sageworks does not report R\&D spending. There is substantial evidence linking IPOs to subsequent

\footnotetext{
${ }^{19}$ Complete results using the two $Q$ measures are available on request.
} 
increases in $R \& D$, suggesting that the stock market is an important source of funding for R\&D projects (Kim and Weisbach (2008), Brown, Fazzari, and Petersen (2009)). Omitting R\&D from the dependent variable would then bias our results if public firms' R\&D spending was more sensitive to changes in investment opportunities than private firms', sufficiently so to outweigh the lower sensitivity of public firms' fixed investment spending. While the absence of R\&D data in Sageworks prevents us from testing this hypothesis directly, we can assess its plausibility indirectly. To do so, we test whether including R\&D spending in the dependent variable increases the estimated investment sensitivity of public firms. Column 4 shows that it does not. The point estimate is 0.042 when we include $R \& D$, marginally greater than the point estimate of $0.136-0.097=0.039$ when we omit R\&D (cf. column 1 of Table 3). On its own, R\&D is thus far from sufficient to close the gap in investment sensitivities between public and private firms. Closing the gap would require that private firms' unobserved R\&D spending correlated negatively with investment opportunities. While this is possible, there is no compelling reason to think it is likely.

\subsubsection{Differences in Tax Treatment or Accounting Choices}

Column 5 restricts the private-firm sample to C Corps, to hold the tax treatment of investment constant. This leaves the coefficient of interest virtually unchanged, with an estimate of $-0.085(p<0.001)$ for the difference in private and public firms' investment sensitivity. Column 6 excludes firms that use cash-basis (rather than accrual) accounting. This too leaves the coefficient of interest barely changed at $0.092(p<0.001)$. In column 7, we model net rather than gross investment and continue to find that private firms are more sensitive to changes in investment opportunities than are public firms $(p<0.001)$.

\subsubsection{Controlling for Further Observable Differences}

Finally, we test whether observable differences between public and private firms that remain after we match on size and industry can account for the observed difference in investment behavior. For example, firms with greater cash holdings or lower leverage might more easily take advantage of improvements in investment opportunities. Omitting cash holdings and leverage would then bias our results, though as Table 1 shows, the effect likely goes in the other direction: Private firms actually hold less cash and are more leveraged than public firms.

In column 8, we add cash holdings and leverage as additional regressors. We also control directly for 
firm size. Gala and Julio (2011) argue that including size can improve the measurement of a firm's true unobserved investment opportunities, for example due to decreasing returns to scale. While each of these additional controls is statistically significant, their inclusion does not alter the finding that public firms are significantly less responsive to changes in investment opportunities. The coefficient for the difference in investment sensitivity between public and private firms is -0.058 with a $p$-value of 0.001 .

\subsection{Measurement Error}

Across all specifications considered in Tables 3 and 4, we find the same result: Public firms are significantly and substantially less responsive to changes in investment opportunities. We now investigate if measurement error in our proxies for investment opportunities might spuriously generate this pattern. Measurement error can lead to attenuation bias so that the estimated investment sensitivity is too low. For this to drive our finding of a lower investment sensitivity among public firms, it would have to be the case that their investment opportunities are measured with relatively more error than those of private firms. We follow two alternative strategies to address this potential concern. First, we investigate this possibility using a standard approach to account for measurement error due to Arellano and Bond (1991). This is a GMM estimator in first-differences which uses lagged regressors as potentially valid instruments under mild assumptions about serial correlation in the measurement error. Second, we exploit a plausibly exogenous tax shock to sidestep the need to directly measure investment opportunities altogether.

\subsubsection{Measurement Error: Arellano-Bond Models}

Table 5 reports the Arellano-Bond results. For ease of comparison, column 1 reproduces the baseline estimates from Table 3. Columns 2 and 3 report models with regressors dated $t-5$ to $t-3$ as instruments. ${ }^{20}$ Column 4 is a system GMM model that jointly estimates a first-differenced equation as in columns 2 and 3 (instrumented with lagged variables in levels) and an equation in levels instrumented with lagged differences (see Blundell and Bond (1998)). The specification in column 5 is dynamic and so includes first lags of all variables. Here, only variables dated $t-5$ and $t-4$ can be used as instruments, which greatly affects identification as our six-year panel is probably too short. Each specification includes year effects.

In all four GMM specifications, we find that private firms' investment behavior is more sensitive to

\footnotetext{
${ }^{20}$ Variables dated $t-2$ are mechanically correlated with lagged sales growth and so cannot be included in the instrument set.
} 
changes in investment opportunities than that of public firms. The difference in investment sensitivity is in fact larger than in the baseline model shown in column 1 , at around -0.2 versus -0.097 . Thus, there appears to be more measurement error for private firms than for public firms, which makes intuitive sense. The difference in investment sensitivity is significant in three of the four models. The exception is the dynamic specification in column 5, perhaps because of the paucity of suitably lagged instruments in our short panel. All four models pass the standard specification tests, i.e., the Hansen test of overidentification restrictions and a test for the absence of third-order serial correlation in first differences.

\subsubsection{Measurement Error: Changes in State Corporate Income Tax}

C Corps are subject to both federal and state income tax. While federal taxes change relatively rarely, there is considerable variation in state taxes across time. Moreover, state taxes change in a staggered way that can be usefully exploited for identification in the spirit of Bertrand and Mullainathan (2003).

A cut in a state's corporate income tax reduces the user cost of capital for firms operating in that state, which should boost investment, and vice versa for tax increases. Changes in state taxes can thus be viewed as shocks to firms' after-tax returns on investment and thus to their investment opportunity sets.

Are tax changes plausibly exogenous? While tax cuts could, potentially, reflect political economy factors (such as firms lobbying the state legislature), it is hard to see why firms would ever lobby for tax increases. As we will show, both tax cuts and tax increases affect investment in our sample.

Our tax experiment asks if private firms are more sensitive to changes in state corporate income taxes than public ones, increasing investment by more when taxes are cut and decreasing it by more when they are raised. We examine this question using a difference-in-difference approach that lets firms' investment sensitivity to tax changes vary by listing status. Using data obtained from the Tax Foundation and verified using state legislature and state department of revenue websites, we identify 19 tax cuts and 14 tax increases over our sample period in a total of 19 states; see Appendix B for details. For example, Kentucky cut its corporate income tax rate from 8.25\% to 7\% from January 2005 .

We code a firm as being affected by a tax change if the state it is headquartered in passed a tax cut or tax increase that came into effect during the fiscal year in question. Since Compustat reports a firm's current - as opposed to historic - location, we verify public firms' historic headquarter states using 10 -K 
and 10-Q filings obtained from the SEC's EDGAR database. ${ }^{21}$ This results in corrections to 132 of the 4,975 public firm-years. Overall in our industry-and-size-matched sample, 138 public and 106 private firms are affected by a tax cut, while 134 public firms and 153 private ones are affected by a tax increase.

Table 6 reports the results. In column 1, we code tax changes using an indicator variable set equal to 1 (-1) for firms affected by a tax cut (tax increase), and zero otherwise. ${ }^{22}$ The results show that private firms - but not public ones - significantly increase investment spending in response to tax cuts and reduce it in response to tax increases. Compared to the unconditional average investment rate among private C Corps in our sample of $9.7 \%$, the point estimate is quite large. All else equal, private firms increase (reduce) investment by $7.2 \%$ of total assets when their home state cuts (increases) corporate income tax. By contrast, public firms' average sensitivity is much lower, at 1.6 percentage points $(0.072-0.056)$, and not statistically significant $(p=0.195){ }^{23}$

Column 2 models tax cuts and tax increases separately. The results are similar: Private firms respond to tax changes while public ones do not. The point estimates are somewhat larger, in absolute terms, for tax cuts than for tax increases, but the data cannot reject the null that the effects are symmetric $(p=0.629)$.

Column 3 investigates possible pre- and post-trends in the tax change effect by adding indicators identifying firms in states that will undergo a tax change in a year's time or that underwent a tax change a year ago. Neither is statistically significant, neither for public nor for private firms.

Before we can interpret these patterns as evidence of private firms showing greater sensitivity to exogenous changes in investment opportunities, we have to consider two possible confounds. The first is due to unobserved differences in geographic dispersion. States levy taxes on all corporate activities within their jurisdiction, regardless of where a firm is headquartered. For example, a firm headquartered in VT with a plant in ME will pay taxes in ME for the income generated by the ME plant. If public firms more often operate in multiple states, their firm-level investment decisions will be less sensitive to a tax change

\footnotetext{
${ }^{21}$ Sageworks' location data is historic and so poses no difficulty.

${ }^{22}$ We use an indicator variable instead of changes in tax rates because many tax changes (e.g., the introduction of a state Alternative Minimum Tax or a tax surcharge) affect a firm's overall tax burden but not marginal tax rates.

${ }^{23}$ Prior studies focus on the effect of tax changes on either public-firm or aggregate investment. For instance, like us, Gruber and Rauh (2007) find a zero elasticity of investment to (federal) tax changes in Compustat data. Using cross-country data, Djankov et al. (2010) show that aggregate investment is sensitive to taxes: A $10 \%$ increase in tax leads to a $2 \%$ drop in aggregate investment to GDP (mean: 21\%). If public-firm investment appears, at least locally, to be insensitive to tax changes, then sensitivity at the aggregate level may be driven, at least in part, by greater sensitivity among private firms.
} 
in their home state. This could potentially explain the lower tax sensitivity of public firms.

To investigate this potential confound, we hand-collect data on the geography of public firms' operations from Item 2 of their 10-K filings. In column 4, we let public firms' sensitivity to tax changes vary according to whether they are a multi-state or a single-state firm at the beginning of that year. The point estimates are similar and not statistically different from each other $(p=0.364)$. Compared to private firms' average tax sensitivity of 8.6 percentage points, the tax sensitivities of single-state and multi-state public firms are a significant 8.8 and 7.2 percentage points lower on average, respectively. Thus, this potential confound does not appear to drive the differential tax sensitivity of public and private firms.

The second potential confound is due to the cash flow consequences of a tax change. Clearly, tax changes affect not only firms' after-tax return on investment but also how much cash flow is available for investment. If private firms are more financially constrained than public firms, changes in state taxes could affect their ability to invest differently even if investment opportunities remained unchanged. This could explain the differential tax sensitivity in Table 6 . To investigate this potential confound, column 5 controls for tax-induced changes in cash flows by including the change in the firm's tax payments between year $t-1$ and $t$, scaled by total assets. The associated coefficients are statistically zero for both public and private firms, suggesting that tax-induced cash flow changes are not a serious confound.

Finally, column 6 reports an indirect validity test of our tax identification strategy. Since in most states, only C Corps are subject to state corporate income taxes, tax changes should have little effect on the investment behavior of private non-C Corps. This is precisely what we find: The coefficient estimate for the tax change indicator in a sample of non-C Corp firms is 0.004 with a standard error of 0.005 .

The results of the tax experiment suggest that private firms are more responsive to changes in investment opportunities than are public firms, even when we sidestep the need to measure investment opportunities and instead exploit exogenous variation in firms' after-tax return on investment.

\subsection{Differences in Investment Sensitivity: IPOs and Within-Firm Variation in Listing Status}

So far, our tests have compared the behavior of public and private firms using matched panels of observably similar firms. While we are the first to have access to comprehensive financial data on a large sample of private firms in the U.S., making such tests possible for the first time, there is a clear 
identification concern: The observed differences in investment could be driven by unobserved differences between public and private firms. This is true of any matching algorithm since matching can only be done on observables. To conclusively rule out possible biases stemming from unobserved heterogeneity would require a randomized trial. However, it is clearly infeasible to randomly assign firms to a stock-market 'treatment' group and a 'control' group of unlisted firms.

In light of this, we explore an alternative research designs that exploits within-firm variation in listing status. To do this, we examine how a given firm's investment behavior changes as it transitions from private to public status. This allows us to remove unobserved time-invariant heterogeneity using firm fixed effects. ${ }^{24}$ Of course, going public is not a natural experiment: Most firms go public for reasons that correlate with investment - usually to fund a planned increase in investment (Brau and Fawcett (2006)). To mitigate problems of the IPO decision affecting investment directly, we focus on firms that go public without raising capital. These firms sell stock belonging to their existing shareholders and so experience increased ownership dispersion and, of necessity, some degree of separation of ownership and control.

This within-firm test reduces identification concerns, but it cannot eliminate them. Unfortunately, the obvious instruments for the IPO decision do not work in our data. In principle, one could exploit discontinuities around stock exchange listing standards to identify the effects of a listing on investment. But in practice, most U.S. listing standards can be satisfied simply by going public, and the remaining standards - concerning profitability - are set so low that they would not be a binding constraint for most of our private firms. ${ }^{25}$ Alternatively, one could use the 2002 Sarbanes-Oxley Act as an exogenous shock to the cost of being public, because compliance with its Section 404 effectively acts as a tax on being a small publicly traded firm. However, our sample post-dates the Act, and while some of its provisions were phased in for small firms, they did not come into force until after the end of our sample period. ${ }^{26}$ As a result, we offer the following evidence in the spirit of a reality check on our large-sample findings.

Our IPO dataset consists of all 90 non-financial and non-utility firms that went public between 1990

\footnotetext{
${ }^{24}$ Gertner, Powers, and Scharfstein (2002), for example, employ this identification strategy, showing that divisions increase their sensitivity to investment opportunities from before to after they are spun off as stand-alone firms by their parent firms.

${ }^{25}$ See http://www.nasdaq.com/about/nasdaq_listing_req_fees.pdf.

${ }^{26}$ Modeling delistings instead is problematic. Exploiting discontinuities around delisting thresholds has poor external validity: Firms forced to delist are usually in trouble and so are not representative of private firms in general (Bakke and Whited (2011)). Internal validity is also poor: Delisting is really a change in trading venue and so need not lead to more concentrated ownership.
} 
and 2007 for the sole purpose of allowing existing shareholders to cash out, as opposed to raising equity to fund operations or investment plans, or to repay debt. Suitable IPOs are identified from Thomson Reuters' SDC database. Appendix C lists their names, dates, and circumstances. We collect post-IPO accounting data from Compustat and hand-collect pre-IPO accounting data from IPO prospectuses and 10-K filings available in the SEC-Edgar and Thomson Research databases. Since this sample does not involve Sageworks data, we can collect data on capital expenditures (CAPEX) and spending on R\&D from the cash flow and income statements. On average, we have 4.4 pre-IPO years of accounting data.

Columns 1 and 2 of Table 7 test if investment sensitivities change around a firm's IPO. The variable of interest interacts investment opportunities with an indicator equal to one if an observation is post-IPO. Whether we measure investment as CAPEX (column 1) or the sum of CAPEX and R\&D (column 2), we find that it is significantly sensitive to investment opportunities before a firm goes public and then becomes significantly less sensitive after the IPO. Thus, firms appear to alter their investment behavior once they are public, even though their IPOs were of the kind that only affected their ownership structure. This finding is consistent with the large-sample evidence reported in our earlier tables.

It is possible that investment sensitivities change for macroeconomic reasons and not because of the IPO itself. To test for this, columns 3 and 4 report difference-in-difference results, combining data from the IPO sample with data for size-and-industry matched public-firm controls. While we cannot rule out that treated and control firms differ in unobserved ways, the results continue to tell the same story: Before they go public, IPO firms have significantly greater investment sensitivities; but once they are public, their sensitivities are not only significantly lower but they become indistinguishable from those of observably similar, public firms.

\section{Potential Explanations}

The results of the three identification strategies reported in Section 3 - matching on observables, the tax experiment, and the IPO approach - all paint the same picture: On average, stock market listed firms are significantly and substantially less responsive to changes in their investment opportunities, despite their relatively easier access to capital. What might account for these differences? As discussed in the introduction, several agency models predict suboptimal investment behavior among public firms. Of 
these, two are consistent with the lower levels of investment we find among public firms: A preference for a quiet life and certain types of short-termism models. In this section, we examine whether agency problems are a plausible cause of the patterns we find and if so, which agency problem is most likely.

For agency problems to be able to explain the patterns we document, it must be the case that private firms are less prone to agency problems. Since such agency problems ultimately are the result of a separation of ownership and control and insufficient incentives for monitoring, a necessary condition for this to be true is that private firms tend to be owner-managed and have more concentrated ownership structures than public firms. We first present evidence consistent with this premise. We then report crosssectional evidence that is consistent with public-firm managers' short-termism being an important driver of the reported differences in investment sensitivities between public and private firms.

\subsection{Do Private Firms Have Fewer Agency Problems?}

We know that our public sample firms have highly dispersed ownership (see Table A7 in the Online Data Appendix), but as Sageworks provides no ownership data, we cannot directly compare ownership structures. Fortunately, Sageworks reports each firm's legal form, and as a point of law, four of these correlate strongly with concentrated ownership and little separation between ownership and control: 1)

Sole proprietorships have a single owner and are by definition owner-managed. 2) For tax purposes and to limit their liability, many sole traders choose LLC status (according to the Federal Reserve's SSBF survey, 67.3\% of LLCs are owner-managed). And both 3) partnerships and 4) LLPs give each partner the statutory right to participate in management and so are usually managed by a committee comprising all partners (in the SSBF, around 90\% of each are owner-managed). In each of these four legal forms, comprising $12 \%$ of the private firms in our Sageworks sample, there is essentially no separation of ownership and control and so little possibility of agency problems distorting investment. This leaves two legal forms that can theoretically have dispersed ownership: C Corps can have an unlimited number of shareholders while S Corps can have up to 100 (or fewer, depending on the state).

Our null hypothesis, which is informed by evidence from the SSBF, is that private C and S Corps in practice have concentrated ownership. The alternative hypothesis is that such firms have dispersed ownership and hence potentially suffer from agency problems. If so, we should find that their investment 
behavior is systematically different from that of the other legal forms.

Table 8 tests this by allowing investment sensitivities among private firms to vary by legal form. Column 1 includes a set of interaction terms for each legal form, capturing differences in investment sensitivities relative to C Corps, in the full private-firm sample. The interaction terms are statistically insignificant, individually and jointly. Thus, investment sensitivities among private firms are no different for sample $\mathrm{C}$ and $\mathrm{S}$ Corps, which potentially have dispersed ownership structures, and the other legal forms, which almost surely have concentrated ownership structures. For robustness, columns 2 and 3 focus on sole proprietorships, which are agency-cost free by definition. In column 2, we compare these to all other private firms, while column 3 matches each by size and industry to a private firm that is not a sole proprietorship, using our earlier matching algorithm. Columns 4 and 5 widen the definition of agency cost-free firms by comparing sole proprietorships, LLCs, partnerships, and LLPs as a group to C and S Corps, using the entire sample (column 4) or a size-and-industry matched sample (column 5).

Each of these five models tells the same story: There is no significant variation in investment sensitivities within the sample of private firms, in contrast to the large variation we found between public and private firms. Since a non-trivial fraction of private firms in our sample are by definition free of agency costs, this suggests that the private firms (including $\mathrm{C}$ and $\mathrm{S}$ Corps) in our sample suffer from fewer investment-distorting agency problems than do the public sample firms.

\subsection{Short-termism: Theory}

These results open the door to agency considerations, and in particular a preference for a quiet life or short-termism, being a driver of the investment differences between public and private firms reported in Section 3. We can shed further light on the importance of such agency considerations by putting some structure on the nature of the possible short-termism. In common with other short-termism models, Stein (1989) assumes that a public-firm manager derives utility from the firm's current stock price as well as from its long-term value. ${ }^{27}$ This gives him an incentive to 'manipulate' the current stock price. Since the stock price equals the present discounted value of the firm's future cash flows, he will try to boost it by

\footnotetext{
${ }^{27}$ The manager may care about the current stock price because he intends to sell some of his stockholdings (as suggested in Stein (1989) and confirmed empirically by Bhojraj et al. (2009)), because his compensation is tied to the stock price (see Garvey, Grant, and King (1999) or Bolton, Scheinkman, and Ziong (2006) for the micro-foundations of such a scheme), or because he fears losing his job in the event of a hostile takeover (Shleifer and Vishny (1990), Stein (1988)).
} 
manipulating investors' expectations of future cash flows. He does so by reporting higher current cash flows, in the hope that investors will increase their expectations of future cash flows in response. The mechanism in short-termism models is not fraudulent accounting (Kedia and Philippon (2009)) but underinvestment. Stein (p. 657) lets the manager "borrow" cash flows from the future by "deciding not to invest in assets that have returns greater than $r$," the firm's cost of capital. In other words, a short-termist manager foregoes positive NPV projects.

Investors do not know the extent of underinvestment but they understand the manager's incentives. They thus realize that high current cash flows might in fact lead to lower future cash flows. In response, they 'discount' the manager's report of current earnings. And yet in equilibrium, the manager will still underinvest. The reason is akin to the prisoners' dilemma: If investors assumed no underinvestment, the manager would inflate current cash flows by cutting investment; and given that investors will, therefore, assume underinvestment, the manager is better off actually underinvesting.

Models of short-termism in the Stein (1989) tradition predict that the extent of a public firm's investment distortion depends on the sensitivity of its share price to its current cash flow. This parameter, which Stein calls $\alpha_{0}$, captures the extent to which investors base their expectations of the firm's future cash flows on its current cash flow. For firms with low $\alpha_{0}$, current cash flows are uninformative about future cash flows and so the manager cannot manipulate investors' expectations and therefore has no incentive to underinvest. Conversely, firms with high $\alpha_{0}$ are firms whose current cash flows are highly informative about their future cash flows. Thus, the higher is $\alpha_{0}$, the greater is the incentive to manipulate investors' expectations by underinvesting and hence the greater is the difference between public and private firms' investment sensitivities.

\subsection{Testable Implications}

Short-termism thus has two cross-sectional implications. First, we expect no distortion for a public firm whose current cash flow is uninformative about future cash flows, that is, whose $\alpha_{0}=0$. In this case, the manager cannot manipulate investors' cash flow expectations, so there is no point making myopic investment decisions. Second, as $\alpha_{0}$ increases, distortions increase. Thus, we expect the difference in 
investment sensitivities between public and private firms to be zero for $\alpha_{0}=0$ and to increase in $\alpha_{0}$. We view these predictions as unique to short-termism as the $\alpha_{0}$ parameter plays no role in alternative stories.

\subsection{Cross-industry Variation in Investment Behavior}

To test these predictions, we follow the accounting literature and measure $\alpha_{0}$ using earnings response coefficients, or ERC (Ball and Brown (1968), Beaver (1968)). ERC measures the sensitivity of a firm's stock price to earnings news and so maps directly into $\alpha_{0}$. As described more fully in Appendix A, we follow Easton and Zmijewski (1989) and estimate a set of industry ERCs for each year from 2001 to $2006 .^{28}$ Industries are defined using Fama and French's (1997) 30 industry groups, which contain enough firms each to estimate ERCs relatively precisely. We also report somewhat noisier results using their finer 48 industries, which contain fewer firms in each industry. We then include a full set of interaction terms involving lagged industry ERCs in our matched-firm investment equation.

Panel A of Table 9 reports the results. In row 1, using Fama-French 30 industries, for ERC $=0$ we find no significant difference in investment sensitivities between public and private firms: The point estimate for private firms is $0.099(p<0.001)$ while that for public firms is an insignificant 0.033 lower $(p=0.355)$. This pattern is consistent with an absence of distortions for $\alpha_{0}=0$, as predicted. As ERC increases, public firms' investment sensitivity decreases significantly $(p=0.033)$ while that of private firms increases somewhat, though not significantly so $(p=0.178)$. In other words, the difference in investment sensitivities between public and private firms increases in ERC, and this increase is driven by a change in public-firm behavior. ${ }^{29}$ The results are similar using Fama-French 48 industries in row 2.

Panel B illustrates the economic magnitudes, showing implied investment sensitivities from Panel A, for private and public firms at the $25^{\text {th }}$ and $75^{\text {th }}$ percentile of the ERC distribution. In low-ERC industries, the investment sensitivity is 0.062 higher for private firms, using Fama-French 30 industries. In high-ERC industries, the difference more than doubles, to 0.141 . The difference in differences of 0.079 is significant. It is driven by a significant decline in sensitivity among public firms, from 0.054 at the $25^{\text {th }}$

\footnotetext{
${ }^{28} \mathrm{We}$ are grateful to Mary Billings for providing the necessary data.

${ }^{29}$ Note that ERC affects investment in Table 9 only through its interaction with investment sensitivities and not directly. This suggests that ERC does not capture some omitted dimension of investment opportunities.
} 
percentile to 0.019 at the $75^{\text {th }}$ percentile. Results look very similar using Fama-French 48 industries.

\subsection{Interpretation}

The findings in Table 9 are consistent with the interpretation that short-termism plays a first-order role in explaining the observed differences in investment behavior between public and private firms in our sample. The negative effect of $\alpha_{0}$ on public (but not private) firms' investment sensitivity fits Stein's (1989) model of short-termism but is not predicted by any other agency model we are aware of. ${ }^{30}$ In particular, it plays no role in the quiet-life hypothesis.

Alternatively, could it be the investment of private firms that is distorted? Maybe private firms respond more strongly to investment opportunities not because they are relatively agency-cost free, but because they are capital-inefficient, inexperienced at making investment decisions, or closet empirebuilders. In light of the results in this section, these alternative interpretations are unlikely. They cannot explain why public and private firms exhibit similar investment sensitivities when $\alpha_{0}=0$ nor why the difference in investment sensitivities between public and private firms increases in $\alpha_{0}$.

\subsection{Cross-industry Variation in the Share of Public Firms}

Our findings have implications for the distribution of public firms across industries. If investment distortions, induced by short-termism, increase in the informativeness of current earnings, and if investors and entrepreneurs understand this, we expect fewer firms to choose to be public in high- $\alpha_{0}$ industries than in low- $\alpha_{0}$ industries, all else equal. We test this prediction by regressing the share of public firms in an industry on the industry's ERC, controlling for its R\&D intensity and capital intensity as other likely drivers of the listing decision. Apart from ERC, our variables are constructed from Census data which restricts us to estimating a single cross-section, for 2007. (See Appendix A for further details.) To ensure we have enough power, we model the share of public firms per four-digit NAICS industry, of which there are 283 , rather than in the 30 or 48 Fama-French industry groups.

In column 1 of Panel $\mathrm{C}$, we measure the share of public firms in an industry as the ratio of the number of public firms (from Compustat) to the total number of firms (from the Census). The controls behave as

\footnotetext{
${ }^{30}$ Nor is it predicted by non-agency stories, such as the idea that public firms are less responsive to changes in investment opportunities simply because they are weighed down by rules and regulations designed to protect minority shareholders.
} 
expected: Significantly more firms are public in industries with greater R\&D or capital intensity. The results for ERC also go in the right direction - there are significantly fewer public firms in industries with higher ERC - but the effect appears quite small economically: A one-standard deviation increase in ERC is associated with a 0.1 percentage point decrease in the share of public firms. This reflects the very large number of small private firms in the economy; in the average industry, 994 in 1,000 firms are private.

A better way to measure the share of public firms is to exclude small firms from the denominator. ${ }^{31}$ Following Chod and Lyandes (2010), who advocate this approach, columns 2 and 3 focus on the share of public firms among firms with at least 100 or at least 500 employees, respectively. The results remain unchanged - there are significantly fewer public firms in high-ERC industries - but the economic magnitudes are larger. In column 2, a one standard deviation increase in ERC leads to a 1.5 percentage point decrease in the share of public firms - a $32.6 \%$ decrease from the $4.6 \%$ unconditional mean share of public firms. The corresponding effect in column 3 is a 3.3 percentage point decrease from the $9.9 \%$ mean. These results are consistent with the interpretation that investors and entrepreneurs view shorttermism as a cost of being publicly listed.

\section{Conclusions}

This paper compares the investment behavior of observably similar public and private firms. Our results show that relative to private firms, public firms invest considerably less and in a way that is significantly less responsive to changes in investment opportunities, especially in industries in which stock prices are quite sensitive to earnings news.

These differences do not appear to be due to unobserved differences between public and private firms: Investment sensitivities among private firms that go public for reasons other than to fund investment are significantly higher pre-IPO and converge on those of observably similar public firms post-IPO. Nor do the results appear to be driven by how we measure investment opportunities, lifecycle differences, or our matching criteria. Interestingly, it seems that the public-private margin is what matters for the effects we observe: We see no differences in investment behavior, among private firms, across different organizational structures (such as sole proprietors, partnerships, or different forms of incorporation).

\footnotetext{
${ }^{31}$ Computing the public-firm share using revenue instead is tricky. Compustat revenue includes foreign sales while the revenue data reported by the Census do not. The resulting ratio is not well behaved: 30 out of 283 industries have ratios greater than 1 .
} 
Our findings are consistent with the presence of a particular type of agency problem. Theorists have long argued that the separation of ownership and control that accompanies a stock market listing can lead to agency problems between managers and dispersed stock market investors and hence to suboptimal investment decisions. The literature is divided on whether overinvestment or underinvestment will result, or indeed whether effective corporate governance mechanisms can be devised to ensure investment does not suffer (Tirole (2001), Shleifer and Vishny (1997)). Our results are most consistent with the view that public firms' investment decisions are affected by managerial short-termism. Managers and investors appear to realize this, in the sense that there are fewer public firms in industries in which investment is expected to be most affected. We find no evidence that looks consistent with empire building or other agency problems that would lead to overinvestment.

We are careful not to claim causality. Short of a trial that randomly assigns firms to public or private status, we cannot categorically rule out endogeneity concerns. However, it is not easy to see how our findings would result from reasonable alternative stories to short-termism. Such stories would not only have to explain why public firms are, on average, less responsive to investment opportunities than private firms, but also why this difference is increasing in the sensitivity of stock prices to earnings news in a firm's industry. 


\section{References}

Abadie, Alberto, and Guido W. Imbens, 2008, On the failure of the bootstrap for matching estimators, Econometrica 76, 1537-1557.

Acharya, Viral V., Heitor Almeida, and Murillo Campello, 2007, Is cash negative debt? A hedging perspective on corporate financial policies, Journal of Financial Intermediation 16, 515-554.

Ang, James S., Rebel A. Cole, and James Wuh Lin, 2000, Agency costs and ownership structure, Journal of Finance 55, 81-106.

Arellano, Manuel, and Stephen Bond, 1991, Some tests of specification for panel data: Monte Carlo evidence and an application to employment equations, Review of Economic Studies 58, 277-297.

Asker, John, Joan Farre-Mensa, and Alexander Ljungqvist, 2010, What Do Private Firms Look like? Data Appendix to "Does the Stock Market Distort Investment Incentives?", Working paper, NYU.

Baber, William R., Patricia M. Fairfield, and James A. Haggard, 1991, The effect of concern about reported income on discretionary spending decisions: The case of research and development, Accounting Review 66, 818-829.

Bakke, Tor-Erik, and Toni Whited, 2010, Which firms follow the market? An analysis of corporate investment decisions, Review of Financial Studies 23, 1941-1980.

Bakke, Tor-Erik, and Toni Whited, 2011, Threshold events and identification: A study of cash shortfalls, Journal of Finance, forthcoming.

Ball, Ray, and Philip Brown, 1968, An empirical evaluation of accounting income numbers, Journal of Accounting Research 6, 159-78.

Baumol, William, 1959, Business Behavior, Value, and Growth (New York, Macmillan).

Beaver, William H., 1968, The information content of annual earnings announcements, Journal of Accounting Research 6, 67-92.

Bebchuk, Lucian A., and Lars A. Stole, 1993, Do short-term objectives lead to under- or overinvestment in long-term projects?, Journal of Finance 48, 719-729.

Berle, Adolf A., and Gardiner C. Means, 1932, The Modern Corporation and Private Property (New York, Macmillan).

Bertrand, Marianne, and Sendhil Mullainathan, 2003, Enjoying the quiet life? Corporate governance and managerial preferences, Journal of Political Economy 111, 1043-1075.

Bharat, Sreedhar, Amy Dittmar, and Jagadeesh Sivadasan, 2010, Does capital market myopia affect plant productivity? Evidence from "going private" transactions, Working paper, University of Michigan.

Bhide, Amar, 1993, The hidden cost of stock market liquidity, Journal of Financial Economics 34, 34-51.

Bhojraj, Sanjeev, Paul Hribar, Marc Picconi, and John McInnis, 2009, Making sense of cents: An examination of firms that marginally miss or beat analyst forecasts, Journal of Finance 64, 2361-2388.

Billett, Matthew T., Tao-Hsien Dolly King, and David C. Mauer, 2007, Growth opportunities and the choice of leverage, debt maturity and covenants, Journal of Finance 62, 697-730.

Bloom, Nick, Stephen Bond, and John van Reenen, 2007, Uncertainty and investment dynamics, Review of Economic Studies 74, 391-415.

Blundell, Richard, and Stephen Bond, 1998, Initial conditions and moment restrictions in dynamic panel data models, Journal of Econometrics 87, 115-143.

Bøhren, Øyvind, Ilan Cooper, and Richard Priestley, 2009, Real investment, economic efficiency, and managerial entrenchment, Working paper, Tel Aviv University. 
Bolton, Patrick, Jose Scheinkman, and Wei Xiong, 2006, Executive compensation and short-termist behavior in speculative markets, Review of Economic Studies 73, 577-610.

Bond, Stephen, and John van Reenen, 2007, Microeconometric models of investment and employment, in: J.J. Heckman and E.E. Leamer (eds.), Handbook of Econometrics Vol. 6 (Amsterdam, Elsevier).

Brau, James C., and Stanley E. Fawcett, 2006, Initial public offerings: An analysis of theory and practice, Journal of Finance 59, 399-436.

Brav, Omer, 2009, Access to capital, capital structure, and the funding of the firm, Journal of Finance 64, 263-208.

Brown, James R., Steven M. Fazzari, and Bruce Petersen, 2009, Financing innovation and growth: Cash flow, external equity, and the 1990s R\&D boom, Journal of Finance 64, 151-185.

Bushee, Brian J., 1998, The influence of institutional investors on myopic R\&D investment behavior, Accounting Review 73, 305-333.

Caballero, Ricardo J., Eduardo M.R.A. Engel, John C. Haltiwanger, Michael Woodford, and Robert E. Hall, 1995, Plant-level adjustment and aggregate investment dynamics, Brookings Papers on Economic Activity, 1-54.

Campello, Murillo, and John Graham, 2007, Do stock prices influence corporate decisions? Evidence from the technology bubble, NBER Working Paper no. 13640.

Chod, Jiri, and Evgeny Lyandes, 2010, Strategic IPOs and product market competition, Journal of Financial Economics, forthcoming.

Cooper, Russell W., and John C. Haltiwanger, 2006, On the nature of capital adjustment costs, Review of Economic Studies 73, 611-633.

Cummins, Jason G., Kevin A. Hassett, and Stephen D. Oliner, 2006, Investment behavior, observable expectations, and internal funds, American Economic Review 96, 796-810.

Dechow, Patricia M., and Richard G. Sloan, 1991, Executive incentives and the horizon problem: An empirical investigation, Journal of Accounting and Economics 14, 51-89.

Djankov, Simeon, Tim Ganser, Rita Ramalho, and Andrei Shleifer, 2010, The effect of corporate taxes on investment and entrepreneurship, American Economic Journal: Macroeconomics 2, 31-64.

Easton, Peter D., and Mark E. Zmijewski, 1989, Cross-sectional variation in the stock market response to accounting earnings announcements, Journal of Accounting and Economics 11, 117-141.

Edgerton, Jesse, 2010, Agency problems in public firms: Evidence from corporate jets in leveraged buyouts, Working paper, Federal Reserve Board.

Edmans, Alex, 2010, Blockholder trading, market efficiency, and managerial myopia, Journal of Finance, forthcoming.

Erickson, Timothy, and Toni Whited, 2000, Measurement error and the relationship between investment and Q, Journal of Political Economy 108, 1027-1057.

Fama, Eugene F., and Kenneth R. French, 1997, Industry costs of equity, Journal of Financial Economics 43, 153-193.

Fang, Vivian W., Xuan Tian, and Sheri Tice, 2010, Does stock liquidity enhance or impede firm innovation?, Working paper, Tulane University.

Fazzari, Steven, R. Glenn Hubbard, and Bruce Petersen, 1988, Financing constraints and corporate investment, Brookings Papers on Economic Activity, 141-195.

Franzoni, Francesco, 2009, Underinvestment vs. overinvestment: Evidence from price reactions to pension contributions, Journal of Financial Economics 92, 491-518. 
Gala, Vito D., and Brandon Julio, 2011, Convergence in corporate investment, Working paper, LBS.

Gao, Huasheng, Michael Lemmon, and Kai Li, 2010, A comparison of CEO pay in public and private U.S. firms, Working paper, University of British Columbia.

Garvey, Gerald T., Simon Grant, and Stephen P. King, 1999, Myopic corporate behavior with optimal management incentives, Journal of Industrial Economics 47, 231-50.

Gertner, Robert, Eric Powers, and David Scharfstein, 2001, Learning about internal capital markets from corporate spin-offs, Journal of Finance 57, 2479-2506.

Gomes, Joao F., 2001, Financing investment, American Economic Review 91, 1263-1285.

Gopalan, Radhakrishnan, Todd Milbourn, Fenghua Song, and Anjan V. Thakor, 2010, The optimal duration of executive compensation: Theory and evidence, Working paper, Washington University in St. Louis.

Graham, John R., Campbell R. Harvey, and Shiva Rajgopal, 2005, The economic implications of corporate financial reporting, Journal of Accounting and Economics 40, 3-73.

Gruber, Jonathan, and Joshua Rauh, 2007, How elastic is the corporate income tax base, in: Alan Auerbach, James Hines, and Joel Slemrod (eds.), Taxing Corporate Income in the 21 st Century (Cambridge, Cambridge University Press).

Hayashi, Fumio, 1982, Tobin's $Q$ and average Q: A neoclassical interpretation, Econometrica 50, 213224.

Holmström, Bengt, 1999, Managerial incentive problems: A dynamic perspective, Review of Economic Studies 66, 169-182.

Holmström, Bengt, 1982, Managerial incentive problems: A dynamic perspective, in: Essays in Economics and Management in Honor of Lars Wahlbeck (Helsinki, Swedish School of Economics).

Imbens, Guido W., and Jeffrey M. Wooldridge, 2009, Recent developments in the econometrics of program evaluation, Journal of Economic Literature 47, 5-86.

Jensen, Michael, and William H. Meckling, 1976, Theory of the firm: Managerial behavior, agency costs and ownership structure, Journal of Financial Economics 3, 305-360.

Jensen, Michael, 1986, Agency cost of free cash flow, corporate finance, and takeovers, American Economic Review 76, 323-32.

Jorgenson, Dale, 1971, Econometric studies of investment behavior: A survey, Journal of Economic Literature 9, 1111-1147.

Jovanovic, Boyan, and Peter L. Rousseau, 2010, Extensive and intensive investment over the business cycle, Working paper, NYU.

Kaplan, Steven, and Luigi Zingales, 1997, Do financing constraints explain why investment is correlated with cash flow?, Quarterly Journal of Economics 112, 169-215.

Kaplan, Steven, and Luigi Zingales, 2000, Investment-cash flow sensitivities are not valid measures of financing constraints, Quarterly Journal of Economics 115, 707-712.

Kedia, Simi, and Thomas Philippon, 2009, The economics of fraudulent accounting, Review of Financial Studies 22, 2169-2199.

Kim, Woojin, and Michael S. Weisbach, 2008, Motivations for public equity offers: An international perspective, Journal of Financial Economics 87, 281-307.

Knyazeva, Anzhela, Diana Knyazeva, Randall Morck, and Bernard Yeung, 2007, Comovement in investment, Working paper, University of Rochester. 
Lehn, Kenneth, and Annette Poulsen, 1989, Free cash flow and stockholder gains in going private transactions, Journal of Finance 44, 771-787.

Ljungqvist, Alexander, and William J. Wilhelm, 2003, IPO pricing in the dot-com bubble, Journal of Finance 58, 723-752.

Martin, Kenneth J., 1996, The method of payment in corporate acquisitions, investment opportunities, and management ownership, Journal of Finance 51, 1227-1246.

Michaely, Roni, and Michael R. Roberts, 2007, Corporate dividend policies: Lessons from private firms, Working paper, Cornell University.

Miller, Merton, and Kevin Rock, 1985, Dividend policy under asymmetric information, Journal of Finance 40, 1031-1051.

Narayanan, M.P., 1985, Managerial incentives for short-term results, Journal of Finance 40, 1469-1484.

Pagano, Marco, Fabio Panetta, and Luigi Zingales, 1998, Why do companies go public? An empirical analysis, Journal of Finance 53, 27-64.

Politis, Dimitris, Joseph Romano, and Michael Wolf, 1999, Subsampling (New York: Springer).

Poterba, James, and Lawrence H. Summers, 1995, A CEO survey of U.S. companies' time horizons and hurdle rates, Sloan Management Review 37, 43-53.

Roychowdhury, Sugata, 2006, Earnings management through real activities manipulation, Journal of Accounting and Economics 42, 335-370.

Rozeff, Michael S., 1982, Growth, beta and agency costs as determinants of dividend payout ratios, Journal of Financial Research 5, 249-259.

Saunders, Anthony, and Sascha Steffen, 2009, The costs of being private: Evidence from the loan market, Working paper, New York University.

Sheen, Albert, 2009, Do public and private firms behave differently? An examination of investment in the chemical industry, Working paper, UCLA.

Shin, Hyun-Han, and René M. Stulz, 1998, Are internal capital markets efficient?, Quarterly Journal of Economics 113, 531-552.

Shleifer, Andrei, and Robert W. Vishny, 1990, Equilibrium short horizons of investors and firms, American Economic Review 80, 148-153.

Shleifer, Andrei, and Robert W. Vishny, 1997, A survey of corporate governance, Journal of Finance 52, 737-783.

Skinner, Douglas J., and Richard G. Sloan, 2002, Earnings surprises, growth expectations, and stock returns or don't let an earnings torpedo sink your portfolio, Review of Accounting Studies 7, 289-312.

Stein, Jeremy C., 1988, Takeover threats and managerial myopia, Journal of Political Economy 96, 61-80.

Stein, Jeremy C., 1989, Efficient capital markets, inefficient firms: A model of myopic corporate behavior, Quarterly Journal of Economics 104, 655-669.

Stein, Jeremy C., 2003, Agency, information and corporate investment, in: Constantinides, G., M. Harris, and R. Stulz (eds.), Handbook of the Economics of Finance (Amsterdam: Elsevier Science).

Stulz, René M., 1990, Managerial discretion and optimal financing policies, Journal of Financial Economics 26, 3-27.

Tirole, Jean, 2001, Corporate governance, Econometrica 69, 1-35.

Von Thadden, Ernst-Ludwig, 1995, Long-term contracts, short-term investment, and monitoring, Review of Economic Studies 62, 557-575. 
Whited, Toni M., 2006, External finance constraints and the intertemporal pattern of intermittent investment, Journal of Financial Economics 81, 467-502.

Wurgler, Jeffrey, 2000, Financial markets and the allocation of capital, Journal of Financial Economics 58, 187-214.

$\mathrm{Xu}$, Moqi, 2011, CEO contract horizon and investment, Working paper, INSEAD. 


\section{Appendix A. Variable Definitions}

Total assets is Compustat item at or its Sageworks equivalent. It is reported in \$ millions of 2000 purchasing power, deflated using the annual GDP deflator, at the beginning of the fiscal year.

Gross investment is the annual increase in gross fixed assets (Compustat data item ppegt or its Sageworks equivalent) scaled by beginning-of-year nominal total assets

Net investment is the annual increase in net fixed assets (Compustat item ppent or its Sageworks equivalent).

Investment (with $R \& D$ ) is capital expenditures plus R\&D expenditures (Compustat items capx $+x r d$ ) scaled by beginning-of-year total assets (Compustat item $a t$ ).

Investment (no $R \& D$ ) is capital expenditures (Compustat item capx) scaled by beginning-of-year total assets (Compustat item $a t)$.

Sales growth is the annual percentage increase in sales (Compustat item sale or its Sageworks equivalent).

Predicted $Q$ is computed as follows. Following Campello and Graham (2007), we regress each public firm's Tobin's $Q$ (Compustat items prcc_f $\times$ cshpri $+p s t k l+d l t t+d l c-t x d i t c$ divided by beginning-of-year total assets, at) on the firm's sales growth, return on assets (ROA, defined as operating income before depreciation scaled by beginning-of-year total assets), net income before extraordinary items, book leverage, and year and industry fixed effects (using 3-digit NAICS industries). We then use the regression coefficients to generate predicted $Q$ for each firm, both public and private ones.

Industry $Q$ is the lagged size-weighted mean of Tobin's $Q$ (Compustat items prcc_f $\times$ cshpri $+p s t k l+d l t t+d l c-t x d i t c$ divided by beginning-of-year total assets, at), estimated separately for each four-digit NAICS industry and each year. We use Compustat total assets ( $a t)$ as weights in computing the size-weighted means.

$\boldsymbol{R O A}$ is operating income before depreciation (Compustat item oibdp or its Sageworks equivalent) scaled by beginningof-year total assets.

Cash holdings is beginning-of-year cash and short-term investments (Compustat item che or its Sageworks equivalent), scaled by beginning-of-year total assets.

Book leverage is beginning-of-year long-term and short-term debt (Compustat items $d l t t+d l c$ or their Sageworks equivalents), scaled by beginning-of-year total assets.

$\boldsymbol{E R C}$ is the earnings response coefficient. Following Easton and Zmijewski (1989), we estimate ERC separately for each industry $j$ and fiscal year $t=2001$ to 2006 by regressing abnormal returns $S A R_{\mathrm{ijt}}$ on a constant and on unexpected earnings $U E_{\mathrm{ijt}}$ using all firms $i$ in industry $j$. $E R C$ for industry $j$ in year $t$ is the coefficient estimated for $U E_{\mathrm{ijt}} . S A R_{\mathrm{ijt}}$ is firm $i$ 's sizeadjusted abnormal return in the five-day window centered on the day the firm announced annual earnings. $U E_{\mathrm{ijt}}$ is firm $i$ 's earnings surprise, measured as actual earnings per share less analyst consensus (i.e., the median outstanding earnings forecast from $\mathrm{I} / \mathrm{B} / \mathrm{E} / \mathrm{S}$ data). We are grateful to Mary Billings for sharing these data with us. We use the Fama and French (1997) classification of either 30 or 48 industry groups, available from Kenneth French's webpage. Once we have an ERC estimate for each Fama-French industry and year, we assign each private firm to a Fama-French industry based on its NAICS code. (We map NAICS codes to SIC codes using the U.S. Census Bureau's NAICS-SIC bridge, available at http://www.census.gov/epcd/naics02/index.html.)

Industry $R \& D$ intensity equals the ratio of total $R \& D$ spending and total revenue in each four-digit NAICS industry, measured in 2007 and covering both public and private firms. Data on corporate R\&D spending by NAICS industry come from the National Science Foundation; see Table 3 at http://www.nsf.gov/statistics/infbrief/nsf09316/. Data on industry revenue come from "Statistics of U.S. Businesses" provided by the Census Bureau. There is no Census data for NAICS codes 111 (Crop production), 112 (Animal production), and 4821 (Rail transportation).

Industry capital intensity equals one minus the ratio of labor costs and total revenue in each four-digit NAICS industry, measured in 2007 and covering both public and private firms. Labor costs are measured as data item "annual payroll" in the Core Business Statistics of the Economic Census. Data on industry revenue come from "Statistics of U.S. Businesses" provided by the Census Bureau.

Net income before extraordinary items is Compustat item $i b$ or its Sageworks equivalent. 


\section{Appendix B. List of State Corporate Income Tax Changes}

This table lists the state corporate income tax changes that we use for the analysis in Table 6 . We list all changes that occurred within one year either side of our sample period (2002-2007) to allow the construction of leads and lags. In states with more than one tax bracket, we report the change to the top bracket; lower tax brackets were usually also affected. To identify these changes, we use data obtained from the Tax Foundation (an abbreviated version of which is available at http://www.taxfoundation.org), and verify the information using each state's Department of Revenue and Legislature websites.

State Date Brief description of tax change

Tax increases:

AL $\quad 1 / 2001 \quad$ Increase in corporate income tax rate from 5\% to $6.5 \%$

AR $1 / 2003$ Introduction of $3 \%$ tax surcharge

CT $\quad 1 / 2004$ Introduction of $25 \%$ tax surcharge

DC $1 / 2004$ Increase in corporate income tax rate from $9.5 \%$ to $9.975 \%$

IA $\quad 1 / 2002$ Introduction of $2.5 \%$ tax surcharge

IL $\quad 1 / 2003$ Introduction of $2.5 \%$ tax surcharge

IN $1 / 2003$ Increase in corporate income tax rate from $3.4 \%$ to $8.5 \%$

KS $\quad 1 / 2002$ Increase in tax surcharge from $3.35 \%$ to $4.5 \%$

KY $\quad 1 / 2002$ Introduction of $3.35 \%$ tax surcharge on income $>\$ 50,000$

MD $1 / 2008$ Increase in corporate income tax rate from $7 \%$ to $8.25 \%$

MI $\quad 1 / 2008$ Increase in corporate income tax rate from $1.9 \%$ to $4.95 \%$

NJ 1/2003 Introduction of an Alternative Minimum Assessment tax based on gross receipts, which applies if it exceeds the corporate franchise tax

NJ $\quad 1 / 2006$ Introduction of $4 \%$ tax surcharge

TN $7 / 2002$ Increase in corporate income tax rate from $6 \%$ to $6.5 \%$

Tax cuts:
AR $\quad 1 / 2006$
Repeal of tax surcharge
AZ $1 / 2001$
Reduction in corporate income tax rate from $7.968 \%$ to $6.968 \%$
CT $\quad 1 / 2006$
Reduction in tax surcharge from $25 \%$ to $20 \%$
CT $1 / 2008$
Repeal of tax surcharge
IA $1 / 2003$
Repeal of tax surcharge
ID $1 / 2001$
Reduction in corporate income tax rate from $8 \%$ to $7.6 \%$
KS $\quad 1 / 2003$
Reduction in tax surcharge from $3.35 \%$ to $4.5 \%$
KS $\quad 7 / 2008$
Reduction in corporate income tax rate from $7.35 \%$ to $7.1 \%$
KY $\quad 1 / 2003$
Repeal of tax surcharge
KY $\quad 1 / 2005$
Reduction in corporate income tax rate from $8.25 \%$ to $7 \%$
KY $\quad 1 / 2007$
Reduction in corporate income tax rate from $7 \%$ to $6 \%$
ND $\quad 1 / 2004$
Reduction in corporate income tax rate from $10.5 \%$ to $7 \%$
ND $\quad 1 / 2007$
Reduction in corporate income tax rate from $7 \%$ to $6.5 \%$
NY $\quad 7 / 2000$
Reduction in corporate income tax rate from $8.5 \%$ to $8 \%$
NY $\quad 7 / 2001$
Reduction in corporate income tax rate from $8 \%$ to $7.5 \%$
NY $\quad 1 / 2007$
Reduction in corporate income tax rate from $7.5 \%$ to $7.1 \%$
VT $\quad 1 / 2006$
Reduction in corporate income tax rate from $9.75 \%$ to $8.9 \%$
VT $1 / 2007$
Reduction in corporate income tax rate from $8.9 \%$ to $8.5 \%$
WV $\quad 1 / 2007$
Reduction in corporate income tax rate from $9 \%$ to $8.75 \%$ 


\section{Appendix C. List of IPO firms}

The sample used in Table 7 consists of 90 U.S. firms that went public on the NYSE, AMEX, or Nasdaq exchanges between 1990 and 2007 for the sole purpose of allowing existing shareholders to cash out, as opposed to raising equity to fund the firm's operations, investment plans, or to repay debt. Suitable IPOs are identified from Thomson Reuters' SDC database. In step 1, we filter on SDC field 'share type offered' to equal S (for secondary IPO, i.e. an IPO in which none of the proceeds is paid to the firm). In step 2, we filter all non-secondary IPOs using SDC field 'use of proceeds' to include SDC codes 13, 18, 40, 79, 91, and 116 (which identify the use of proceeds as being a stock repurchase, the payment of a dividend, or redemption of preferred securities). In step 3, we verify, using IPO prospectuses, that the sole purpose of the non-secondary IPOs was indeed to allow shareholders to cash out and drop IPOs whose use of proceeds included the funding of operations, investments plans, or debt repayment. We exclude financial firms (SIC 6), regulated utilities (SIC 49), government entities (SIC 9), and firms with CRSP share codes greater than 11 (such as mutual funds).

\begin{tabular}{|c|c|c|}
\hline IPO date & Name of IPO firm & Purpose of IPO/use of proceeds \\
\hline 12-Apr-90 & RMI Titanium Co & Secondary IPO (some pre-IPO shareholders selling out) \\
\hline 26-Jul-90 & Banner Aerospace Inc & Secondary IPO (some pre-IPO shareholders selling out) \\
\hline 18-Sep-90 & Pamida Holdings Corp & Secondary IPO (some pre-IPO shareholders selling out) \\
\hline 11-Nov-91 & Bally Gaming International Inc & Secondary IPO (some pre-IPO shareholders selling out) \\
\hline 25-Nov-91 & Broderbund Software Inc & Secondary IPO (some pre-IPO shareholders selling out) \\
\hline 30-Jan-92 & ElectroCom Automation Inc & Secondary IPO (some pre-IPO shareholders selling out) \\
\hline 12-Feb-92 & TNT Freightways Corp & Secondary IPO (some pre-IPO shareholders selling out) \\
\hline $13-F e b-92$ & Living Centers of America Inc & Secondary IPO (some pre-IPO shareholders selling out) \\
\hline 30-Mar-92 & Eskimo Pie Corp & Secondary IPO (some pre-IPO shareholders selling out) \\
\hline 28-Apr-92 & Ben Franklin Retail Stores Inc & Secondary IPO (some pre-IPO shareholders selling out) \\
\hline 29-Apr-93 & Geon Co & Secondary IPO (some pre-IPO shareholders selling out) \\
\hline 10-Jun-93 & Department 56 Inc & Secondary IPO (some pre-IPO shareholders selling out) \\
\hline 29-Sep-93 & Belden Inc & Secondary IPO (some pre-IPO shareholders selling out) \\
\hline 10-Dec-93 & Camco International Inc & Secondary IPO (some pre-IPO shareholders selling out) \\
\hline 26-Jan-94 & O’Sullivan Industries Holdings & Secondary IPO (some pre-IPO shareholders selling out) \\
\hline 27-Jan-94 & Interim Services Inc & Secondary IPO (some pre-IPO shareholders selling out) \\
\hline 10-May-94 & Advocat Inc & Secondary IPO (some pre-IPO shareholders selling out) \\
\hline 25-May-94 & Merix Corp & Secondary IPO (some pre-IPO shareholders selling out) \\
\hline 24-Jun-94 & Case Corp & Secondary IPO (some pre-IPO shareholders selling out) \\
\hline 30-Jun-94 & Rawlings Sporting Goods Co & Secondary IPO (some pre-IPO shareholders selling out) \\
\hline 27-Sep-94 & Sterile Concepts Inc & Secondary IPO (some pre-IPO shareholders selling out) \\
\hline 08-Nov-94 & Thompson PBE Inc & Repurchase redeemable capital stock from pre-IPO shareholders \\
\hline 01-Feb-95 & Congoleum Corporation & Repurchase Class B stock from pre-IPO shareholders \\
\hline 06-Mar-95 & Dollar Tree Stores Inc & Redeem preferred stock from pre-IPO shareholders \\
\hline 06-Mar-95 & Riviana Foods Inc & Secondary IPO (some pre-IPO shareholders selling out) \\
\hline 06-Sep-95 & Ballantyne of Omaha Inc & Secondary IPO (some pre-IPO shareholders selling out) \\
\hline 21-Sep-95 & Midwest Express Holdings Inc & Secondary IPO (some pre-IPO shareholders selling out) \\
\hline 14-Nov-95 & Lexmark International Group & Secondary IPO (some pre-IPO shareholders selling out) \\
\hline 25-Jan-96 & World Color Press Inc & Secondary IPO (some pre-IPO shareholders selling out) \\
\hline 01-Mar-96 & Berg Electronics Corp & Redeem preferred stock from pre-IPO shareholders \\
\hline 28-Mar-96 & Century Aluminum Co & Secondary IPO (some pre-IPO shareholders selling out) \\
\hline 03-Apr-96 & Lucent Technologies Inc & Secondary IPO (some pre-IPO shareholders selling out) \\
\hline 27-Jun-96 & FactSet Research Systems Inc & Secondary IPO (some pre-IPO shareholders selling out) \\
\hline 25-Jul-96 & Strayer Education Inc & Pay S Corp dividend to pre-IPO shareholders \\
\hline 15-Aug-96 & Consolidated Cigar Holdings Inc & Pay dividend to parent \\
\hline 09-Oct-96 & Splash Technology Holdings Inc & Redeem preferred stock from pre-IPO shareholders \\
\hline 25-Nov-96 & Linens $n$ Things Inc & Secondary IPO (some pre-IPO shareholders selling out) \\
\hline 17-Dec-96 & Swisher International Group Inc & Pay dividend to parent \\
\hline 15-May-97 & General Cable Corp & Secondary IPO (some pre-IPO shareholders selling out) \\
\hline 10-Oct-97 & Stoneridge Inc & Secondary IPO (some pre-IPO shareholders selling out) \\
\hline 15-Oct-97 & CH Robinson Worldwide Inc & Secondary IPO (some pre-IPO shareholders selling out) \\
\hline 23-Oct-97 & ITC Deltacom Inc & Secondary IPO (some pre-IPO shareholders selling out) \\
\hline 11-Dec-97 & Spectra Physics Lasers Inc & Secondary IPO (some pre-IPO shareholders selling out) \\
\hline
\end{tabular}




\begin{tabular}{|c|c|c|}
\hline IPO date & Name of IPO firm & Purpose of IPO/use of proceeds \\
\hline 28-Jan-98 & Keebler Foods Co & Secondary IPO (some pre-IPO shareholders selling out) \\
\hline 17-Feb-98 & Steelcase Inc & Secondary IPO (some pre-IPO shareholders selling out) \\
\hline 26-Mar-98 & Columbia Sportswear Co & Secondary IPO (some pre-IPO shareholders selling out) \\
\hline 22-Jul-98 & USEC Inc & Secondary IPO (some pre-IPO shareholders selling out) \\
\hline 21-Oct-98 & Conoco & Secondary IPO (some pre-IPO shareholders selling out) \\
\hline 22-Feb-99 & Corporate Executive Board Co & Secondary IPO (some pre-IPO shareholders selling out) \\
\hline 09-Jun-99 & DiTech Corp & Redeem preferred stock from pre-IPO shareholders \\
\hline 09-Nov-99 & United Parcel Service Inc $\{$ UPS $\}$ & Redeem A Class shares from pre-IPO shareholders \\
\hline 17-Nov-99 & Agilent Technologies Inc & Pay dividend to parent \\
\hline 27-Jan-00 & Packaging Corp of America & Redeem preferred stock from pre-IPO shareholders \\
\hline 04-Apr-00 & Cabot Microelectronics Corp & Pay dividend to parent \\
\hline 10-Jul-00 & Axcelis Technologies Inc & Pay dividend to parent \\
\hline 27-Mar-01 & Agere Systems Inc & Secondary IPO (some pre-IPO shareholders selling out) \\
\hline 12-Nov-01 & Advisory Board Co & Secondary IPO (some pre-IPO shareholders selling out) \\
\hline 14-Nov-01 & Weight Watchers Intl Inc & Secondary IPO (some pre-IPO shareholders selling out) \\
\hline 10-Dec-01 & Aramark Worldwide Corp & Repurchase stock from company's retirement plan \\
\hline 10-Jul-02 & Kirkland's Inc & Repurchase preferreds and common stock from pre-IPO shareholders \\
\hline 14-Nov-02 & Constar International Inc & Secondary IPO (some pre-IPO shareholders selling out) \\
\hline 24-Sep-03 & Anchor Glass Container Corp & Redeem Series C participating preferreds from pre-IPO shareholders \\
\hline $30-$-Oct- 03 & Overnite Corp & Secondary IPO (some pre-IPO shareholders selling out) \\
\hline 19-Nov-03 & Whiting Petroleum Corp & Secondary IPO (some pre-IPO shareholders selling out) \\
\hline 24-Nov-03 & Pinnacle Airlines Corp & Secondary IPO (some pre-IPO shareholders selling out) \\
\hline 11-Dec-03 & Compass Minerals Intl Inc & Secondary IPO (some pre-IPO shareholders selling out) \\
\hline 13-Jan-04 & CrossTex Energy Inc & Secondary IPO (some pre-IPO shareholders selling out) \\
\hline 04-Feb-04 & TODCO & Secondary IPO (some pre-IPO shareholders selling out) \\
\hline 16-Jun-04 & ADESA Inc & Repurchase stock from company's retirement plan \\
\hline 21-Jun-04 & Jackson Hewitt Tax Service Inc & Secondary IPO (some pre-IPO shareholders selling out) \\
\hline 21-Jul-04 & Blackbaud Inc & Secondary IPO (some pre-IPO shareholders selling out) \\
\hline 06-Aug-04 & NAVTEQ Corp & Secondary IPO (some pre-IPO shareholders selling out) \\
\hline 08-Dec-04 & Foundation Coal Holdings Inc & Pay dividend to pre-IPO shareholders \\
\hline 20-Jan-05 & Celanese Corp & Pay dividend to pre-IPO shareholders \\
\hline 27-Jan-05 & W\&T Offshore Inc & Secondary IPO (some pre-IPO shareholders selling out) \\
\hline 08-Feb-05 & FTD Group Inc & Repurchase preferred stock and junior preferred stock from pre-IPO shareholders \\
\hline 02-May-05 & Morningstar Inc & Secondary IPO (some pre-IPO shareholders selling out) \\
\hline 13-Jun-05 & Premium Standard Farms Inc & Secondary IPO (some pre-IPO shareholders selling out) \\
\hline 28-Jun-05 & NeuStar Inc & Secondary IPO (some pre-IPO shareholders selling out) \\
\hline 22-Jul-05 & Maidenform Brands Inc & Redeem all outstanding shares of preferred stock from pre-IPO shareholders \\
\hline 04-Aug-05 & Dresser-Rand Group Inc & Pay dividend to pre-IPO shareholders \\
\hline 08-Aug-05 & K\&F Industries Holdings Inc & Redeem junior preferred stock from pre-IPO shareholders; pay a special dividend \\
\hline $10-$ Nov-05 & IHS Inc & Secondary IPO (some pre-IPO shareholders selling out) \\
\hline 21-Nov-05 & Tronox Inc & Pay dividend to parent \\
\hline 14-Mar-06 & Transdigm Group Inc & Secondary IPO (some pre-IPO shareholders selling out) \\
\hline 03-May-06 & DynCorp International Inc & $\begin{array}{l}\text { Redeem preferred stock from pre-IPO shareholders, pay prepayment penalties, } \\
\text { and pay a special dividend }\end{array}$ \\
\hline 27-Jun-06 & J Crew Group Inc & Redeem preferred stock from pre-IPO shareholders \\
\hline 25-Jul-06 & Chart Industries Inc & Pay dividend to pre-IPO shareholders \\
\hline 28-Feb-07 & Coleman Cable Inc & Secondary IPO (some pre-IPO shareholders selling out) \\
\hline 12-Jun-07 & Bway Holding Co & Secondary IPO (some pre-IPO shareholders selling out) \\
\hline
\end{tabular}




\section{Figure 1. Size Distribution of Public and Private Sample Firms.}

The top graph shows the size distribution of the public and private firms in our full samples of Compustat and Sageworks firms The bottom graph shows the size distribution of the public and private firms in our matched sample. The graphs present, for each set of firms, Epanechnikov kernel densities of the natural logarithm of total assets in \$ millions of 2000 purchasing power. The width of the kernel density window around each point is set to 0.4 . The unit of observation in the top graph is a firm. The unit of observation in the bottom graph is a firm-year, to illustrate the closeness of the matched panels.

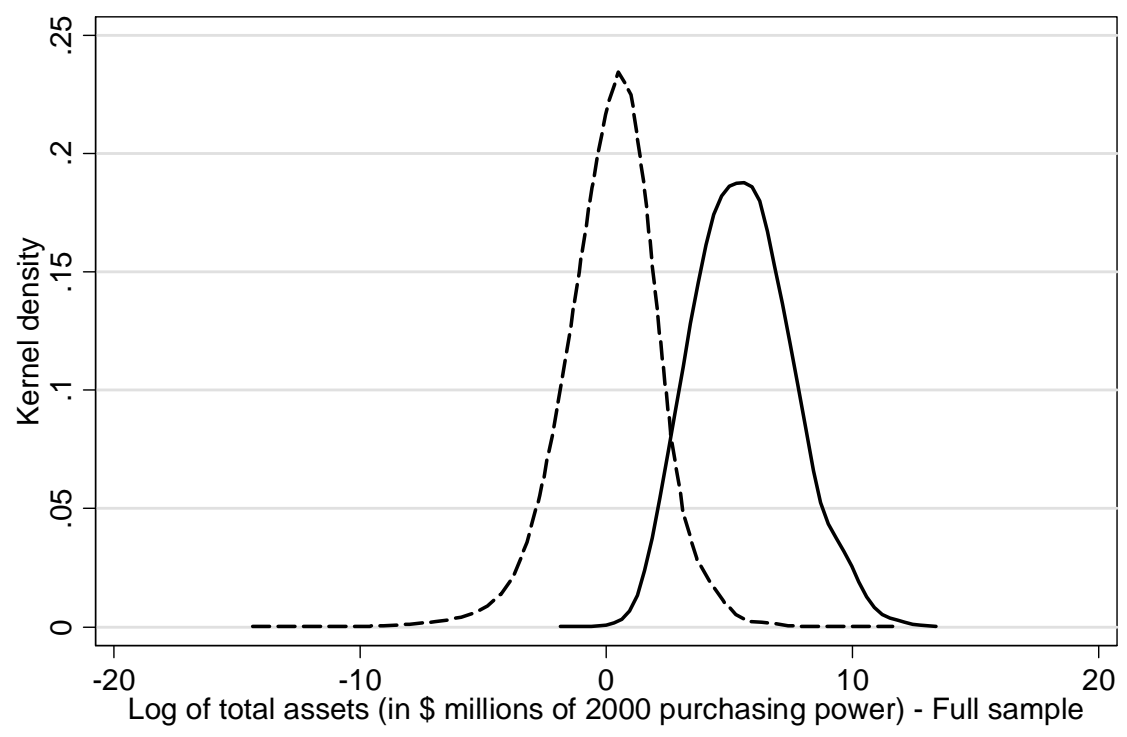

Public companies ----- Private companies

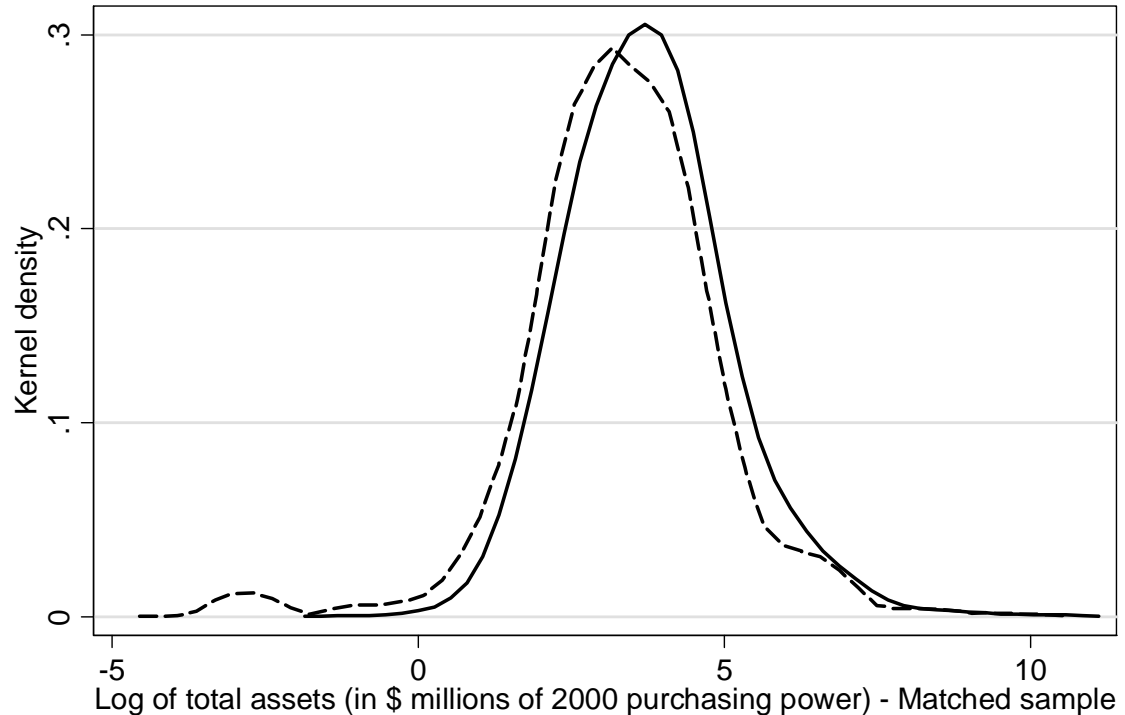

Public companies - - - - Private companies 
Table 1. Descriptive Statistics.

This table presents descriptive statistics for the full samples of public and private firms and for a size-and-industry matched sample over the period from 2002 to 2007. See Section 2.1 for a description of how we construct the full samples from Compustat and Sageworks data and Section 2.2 for details of the matching procedure. The table reports means, medians, and standard deviations of the key variables used in our empirical analysis as well as pairwise differences in means and medians, with ${ }^{* * *}$ and ${ }^{* *}$ indicating a difference that is significant in a $t$-test (for means) or a Pearson $\chi^{2}$ test (for medians) at the $1 \%$ and $5 \%$ level, respectively. For variable definitions and details of their construction, see Appendix A. All variables (except industry $Q$ and predicted $Q$ ) are winsorized $0.5 \%$ in each tail to reduce the impact of outliers.

\begin{tabular}{|c|c|c|c|c|c|c|c|}
\hline & \multicolumn{3}{|c|}{ Full sample } & \multicolumn{3}{|c|}{ Matched sample } \\
\hline & & $\begin{array}{c}\text { Public } \\
\text { firms }\end{array}$ & $\begin{array}{c}\text { Private } \\
\text { firms }\end{array}$ & $\begin{array}{c}\text { Differences } \\
\text { in means or } \\
\text { medians }\end{array}$ & $\begin{array}{c}\text { Public } \\
\text { firms }\end{array}$ & $\begin{array}{c}\text { Private } \\
\text { firms }\end{array}$ & $\begin{array}{c}\text { Differences in } \\
\text { means or } \\
\text { medians }\end{array}$ \\
\hline \multicolumn{8}{|l|}{ Firm size } \\
\hline \multirow[t]{3}{*}{ Total assets $(\$ \mathrm{~m})$} & mean & $1,364.4$ & 7.1 & $1,357.3^{* * *}$ & 144.7 & 120.0 & 24.7 \\
\hline & median & 246.2 & 1.3 & $245.0^{* * *}$ & 40.3 & 28.0 & $12.3^{* * *}$ \\
\hline & st.dev. & $2,958.1$ & 190.2 & & 692.8 & 675.5 & \\
\hline \multicolumn{8}{|c|}{ Investment opportunities } \\
\hline \multirow[t]{3}{*}{ Sales growth } & mean & 0.183 & 0.177 & 0.006 & 0.256 & 0.327 & $-0.071^{* * *}$ \\
\hline & median & 0.087 & 0.070 & $0.016^{* * *}$ & 0.091 & 0.111 & $-0.020^{* * *}$ \\
\hline & st.dev. & 0.674 & 0.652 & & 0.925 & 1.075 & \\
\hline \multirow[t]{3}{*}{ Industry $Q$} & mean & 1.747 & 1.398 & $0.349^{* * *}$ & 1.838 & 1.838 & 0.000 \\
\hline & median & 1.579 & 1.235 & $0.344^{* * *}$ & 1.753 & 1.753 & 0.000 \\
\hline & st.dev. & 0.840 & 0.613 & & 0.740 & 0.740 & \\
\hline \multirow[t]{3}{*}{ Predicted $Q$} & mean & 1.817 & 1.473 & $0.344^{* * *}$ & 2.119 & 1.964 & $0.155^{* * *}$ \\
\hline & median & 1.778 & 1.385 & $0.393^{* * *}$ & 2.047 & 1.889 & $0.158^{* * *}$ \\
\hline & st.dev. & 0.663 & 1.082 & & 0.774 & 1.229 & \\
\hline \multicolumn{8}{|l|}{ Firm characteristics } \\
\hline \multirow[t]{3}{*}{ ROA } & mean & 0.065 & 0.075 & $-0.010^{* *}$ & -0.060 & 0.084 & $-0.144^{* * *}$ \\
\hline & median & 0.111 & 0.095 & $0.016^{* * *}$ & 0.051 & 0.123 & $-0.072^{* * *}$ \\
\hline & st.dev. & 0.286 & 1.069 & & 0.437 & 0.986 & \\
\hline \multirow[t]{3}{*}{ Cash holdings } & mean & 0.225 & 0.152 & $0.073^{* * *}$ & 0.304 & 0.151 & $0.152^{* * *}$ \\
\hline & median & 0.131 & 0.073 & $0.058^{* * *}$ & 0.228 & 0.074 & $0.154^{* * *}$ \\
\hline & st.dev. & 0.239 & 0.202 & & 0.267 & 0.200 & \\
\hline \multirow[t]{3}{*}{ Book leverage } & mean & 0.199 & 0.311 & $-0.111^{* * *}$ & 0.149 & 0.218 & $-0.069^{* * *}$ \\
\hline & median & 0.145 & 0.157 & $-0.012^{* * *}$ & 0.055 & 0.132 & $-0.077^{* * *}$ \\
\hline & st.dev. & 0.230 & 0.455 & & 0.250 & 0.264 & \\
\hline \multicolumn{2}{|l|}{ No. of observations } & 19,203 & 88,568 & & 4,975 & 4,975 & \\
\hline \multicolumn{2}{|l|}{ No. of firms } & 3,926 & 32,204 & & 1,666 & 620 & \\
\hline
\end{tabular}


Table 2. Investment Levels.

This table compares the investment levels of public and private firms for the full samples of Compustat and Sageworks firms, our size-and-industry matched samples, and various variations of our basic matching specification. For details on the matching approach see Section 2.2. The table reports means, medians, and standard deviations of investment levels of public and private firms under the different matching specifications, as well as pairwise differences in means and medians, with ${ }^{* * *}$ and ${ }^{* *}$ indicating a difference that is significant in a -test (for means) or a Pearson $\chi^{2}$ test (for medians) at the $1 \%$ and $5 \%$ level, respectively. For variable definitions and details of their construction, see Appendix A. Investment levels are winsorized $0.5 \%$ in each tail to reduce the impact of outliers. The last four rows investigate potential confounds. 'Old' public firms are those whose timesince-IPO in their first year in our panel exceeds the median time-since-IPO of all public firms in the same calendar year. Age for private firms is not available in Sageworks, so we continue to match on size and industry but not on age. The last two rows restrict the sample to C Corps (in order to hold tax regime constant between public and private firms) and to firms using accrual-basis rather than cash accounting, respectively.

\begin{tabular}{|c|c|c|c|c|c|c|c|c|c|c|c|c|c|}
\hline \multirow[b]{2}{*}{ Sample } & \multirow{2}{*}{$\begin{array}{l}\text { Invest } \\
\text { ment } \\
\text { mea- } \\
\text { sure }\end{array}$} & \multicolumn{5}{|c|}{ Public firms } & \multicolumn{5}{|c|}{ Private firms } & \multicolumn{2}{|c|}{ Public - private firms } \\
\hline & & Mean & $\begin{array}{l}\text { Std. } \\
\text { dev. }\end{array}$ & Median & $\begin{array}{l}\text { No. of } \\
\text { obs. }\end{array}$ & $\begin{array}{l}\text { No. of } \\
\text { firms }\end{array}$ & Mean & $\begin{array}{l}\text { Std. } \\
\text { dev. }\end{array}$ & Median & $\begin{array}{l}\text { No. of } \\
\text { obs. }\end{array}$ & $\begin{array}{c}\text { No. of } \\
\text { firms }\end{array}$ & $\begin{array}{l}\text { Diff. in } \\
\text { means }\end{array}$ & $\begin{array}{l}\text { Diff. in } \\
\text { medians }\end{array}$ \\
\hline \multirow[t]{2}{*}{ Full sample } & Gross & 0.045 & 0.154 & 0.023 & 19,203 & 3,926 & 0.076 & 0.261 & 0.017 & 88,568 & 32,204 & $-0.031^{* * *}$ & $0.005^{* * *}$ \\
\hline & Net & 0.022 & 0.123 & 0.002 & 19,203 & 3,926 & 0.033 & 0.205 & 0.000 & 88,568 & 32,204 & $-0.011^{* * *}$ & $0.002^{* * *}$ \\
\hline \multicolumn{14}{|l|}{ Samples matched on: } \\
\hline \multirow[t]{2}{*}{ NAICS4, total assets } & Gross & 0.040 & 0.191 & 0.017 & 4,975 & 1,666 & 0.097 & 0.304 & 0.016 & 4,975 & 620 & $-0.056^{* * *}$ & 0.001 \\
\hline & Net & 0.022 & 0.150 & 0.000 & 4,975 & 1,666 & 0.094 & 0.302 & 0.009 & 4,975 & 620 & $-0.072^{* * *}$ & $-0.009^{* * *}$ \\
\hline NAICS5, total assets & Gross & 0.042 & 0.197 & 0.017 & 4,320 & 1,483 & 0.099 & 0.296 & 0.016 & 4,320 & 566 & $-0.057^{* * *}$ & 0.001 \\
\hline NAICS6, total assets & Gross & 0.043 & 0.209 & -0.001 & 1,462 & 558 & 0.137 & 0.362 & 0.016 & 1,462 & 223 & $-0.095^{* * *}$ & $-0.017^{* * *}$ \\
\hline NAICS4, total assets, sales growth & Gross & 0.047 & 0.170 & 0.021 & 7,273 & 2,578 & 0.086 & 0.244 & 0.022 & 7,273 & 1,635 & $-0.039^{* * *}$ & -0.001 \\
\hline $\begin{array}{l}\text { NAICS4, total assets, sales } \\
\text { growth, ROA, cash, and debt }\end{array}$ & Gross & 0.049 & 0.171 & 0.022 & 7,413 & 2,618 & 0.079 & 0.270 & 0.015 & 7,413 & 1,809 & $-0.030^{* * *}$ & $0.007^{* * *}$ \\
\hline NAICS4, total assets, restricted to & & & & & & & & & & & & & \\
\hline old public firms & Gross & 0.032 & 0.166 & 0.016 & 2,014 & 624 & 0.092 & 0.285 & 0.016 & 2,014 & 360 & $-0.061^{* * *}$ & 0.000 \\
\hline young public firms & Gross & 0.046 & 0.206 & 0.018 & 2,961 & 1,042 & 0.100 & 0.316 & 0.017 & 2,961 & 456 & $-0.054^{* * *}$ & 0.001 \\
\hline C Corps & Gross & 0.023 & 0.154 & 0.000 & 4,077 & 1,472 & 0.093 & 0.308 & 0.008 & 4,077 & 441 & $-0.071^{* * *}$ & $-0.008^{* * *}$ \\
\hline accrual basis accounting & Gross & 0.040 & 0.191 & 0.017 & 4,914 & 1,644 & 0.091 & 0.280 & 0.016 & 4,914 & 611 & $-0.050^{* * *}$ & 0.001 \\
\hline
\end{tabular}




\section{Table 3. Sensitivity To Investment Opportunities.}

This table exploits within-firm variation to analyze differences in the sensitivity of investment spending to investment opportunities between public and private firms. The dependent variable is gross investment (the annual increase in gross fixed assets scaled by beginning-of-year total assets). We obtain similar results using net investment (the scaled increase in net fixed assets); see column 7 in Table 4. We use three different measures of investment opportunities: Sales growth, our preferred measure (columns 1 through 5); industry $Q$ (column 6); and predicted $Q$ (column 7). For variable definitions and details of their construction, see Appendix A. Note that we lose a small number of observations for four firms in column 7 due to missing leverage data, which is used in the construction of predicted $Q$. Following parts of the empirical investment literature, all specification include ROA, sometimes interpreted as a possible proxy for financing constraints. Our baseline specification in column 1 uses a size-and-industry matched sample based on fourdigit NAICS industries. (See Section 2.2 for further details of the matching.) Columns 2 and 3 investigate robustness to matching on finer industry classifications. In columns 4 and 5 , we add further matching criteria to the baseline specification. Column 4 matches on sales growth in addition to total assets and NAICS4 industry while column 5 matches on industry, total assets, sales growth, ROA, cash holdings, and book leverage. Each specification uses a nearest-neighbor propensity score match with a 5\% caliper. All regressions include firm fixed effects. Since the sample contains no firms that transition from public to private status or vice versa, inclusion of firm fixed effects implies that we cannot identify differences in investment levels between public and private firms in these regressions. Each regression also includes year effects; their coefficients are not reported to conserve space. The data panel is set up in calendar time; fiscal years ending January 1 through May 31 are treated as ending in the prior calendar year. Heteroskedasticityconsistent standard errors clustered at the firm level are shown in italics underneath the coefficient estimates in all columns except for column 7 , where the standard errors are obtained by bootstrapping in order to account for the fact that predicted $Q$ is an estimated regressor. When bootstrapping, we use the matched public-private firm pairs as resampling clusters and perform 500 replications. We use ${ }^{* * *},{ }^{* *}$, and ${ }^{*}$ to denote significance at the $1 \%, 5 \%$, and $10 \%$ level (two-sided), respectively. All continuous variables are winsorized $0.5 \%$ in each tail to reduce the impact of outliers, except industry $Q$ (which is a size-weighted average and so already downweights outliers) and predicted $Q$ (which is itself constructed from winsorized data).

\begin{tabular}{|c|c|c|c|c|c|c|c|}
\hline \multirow[b]{2}{*}{ Measure of investment opportunities: } & \multicolumn{7}{|c|}{ Dependent variable: Gross investment / lagged total assets } \\
\hline & \multicolumn{5}{|c|}{ Sales growth } & \multirow[b]{2}{*}{$\begin{array}{c}\text { Industry } Q \\
\\
\text { Matched on } \\
\text { size and } \\
\text { industry } \\
\text { (NAICS4) } \\
(6) \\
\end{array}$} & \multirow[b]{2}{*}{$\begin{array}{c}\text { Predicted } Q \\
\\
\text { Matched on } \\
\text { size and } \\
\text { industry } \\
\text { (NAICS4) } \\
(7) \\
\end{array}$} \\
\hline Sample & $\begin{array}{c}\text { Matched on } \\
\text { size and } \\
\text { industry } \\
\text { (NAICS4) } \\
(1)\end{array}$ & $\begin{array}{c}\text { Matched on } \\
\text { size and } \\
\text { industry } \\
\text { (NAICS5) } \\
(2)\end{array}$ & $\begin{array}{c}\text { Matched on } \\
\text { size and } \\
\text { industry } \\
\text { (NAICS6) } \\
(3)\end{array}$ & $\begin{array}{c}\text { Matched on } \\
\text { size, sales } \\
\text { growth \& } \\
\text { industry } \\
\text { (NAICS4) } \\
(4) \\
\end{array}$ & $\begin{array}{c}\text { Matched on } \\
\text { size, sales } \\
\text { growth, ROA, } \\
\text { cash, debt \& } \\
\text { industry } \\
\text { (NAICS4) } \\
(5)\end{array}$ & & \\
\hline \multirow[t]{2}{*}{ Investment opportunities } & $0.136^{* * *}$ & $0.135^{* * *}$ & $0.186^{* * *}$ & $0.098^{* * *}$ & $0.081^{* * *}$ & $0.148^{* * *}$ & $0.383^{* * *}$ \\
\hline & 0.013 & 0.016 & 0.055 & 0.020 & 0.022 & 0.055 & 0.030 \\
\hline \multirow[t]{2}{*}{ Investment opp. $\mathrm{x}$ public } & $-0.097^{* * *}$ & $-0.099^{* * *}$ & $-0.143^{* *}$ & $-0.061^{* * *}$ & $-0.048^{* *}$ & $-0.147^{* * *}$ & $-0.226^{* * *}$ \\
\hline & 0.015 & 0.018 & 0.057 & 0.021 & 0.023 & 0.053 & 0.030 \\
\hline \multirow[t]{2}{*}{ ROA } & $0.173^{* * *}$ & $0.171^{* * *}$ & $0.232^{* * *}$ & $0.124^{* * *}$ & $0.102^{* * *}$ & 0.112 & $0.519^{* * *}$ \\
\hline & 0.014 & 0.018 & 0.065 & 0.025 & 0.021 & 0.077 & 0.034 \\
\hline \multirow[t]{2}{*}{ ROA x public } & $-0.135^{* * *}$ & $-0.146^{* * *}$ & $-0.254^{* * *}$ & $-0.076^{* *}$ & -0.041 & -0.063 & $-0.342^{* * *}$ \\
\hline & 0.027 & 0.029 & 0.077 & 0.036 & 0.034 & 0.080 & 0.042 \\
\hline$R^{2}$ (within) & $29.6 \%$ & $26.5 \%$ & $17.4 \%$ & $18.1 \%$ & $11.7 \%$ & $15.1 \%$ & $28.1 \%$ \\
\hline$F$-test: all coeff. $=0$ & $32.1^{* * *}$ & $19.9^{* * *}$ & $2.9^{* * *}$ & $7.8^{* * *}$ & $8.6^{* * *}$ & $3.0^{* * *}$ & $15.1^{* * *}$ \\
\hline No. observations & 9,950 & 8,640 & 2,924 & 14,546 & 14,826 & 9,950 & 9,931 \\
\hline No. firms & 2,286 & 2,049 & 781 & 4,213 & 4,427 & 2,286 & 2,282 \\
\hline
\end{tabular}




\section{Table 4. Alternative Specifications.}

As in Table 3, we use sales growth to proxy for investment opportunities and exploit within-firm variation using OLS with firm and year fixed effects. Columns 1-3 investigate lifecycle stories of investment. Column 1 restricts the sample of public firms to 'old' firms (those whose time-since-IPO in their first year in our panel exceeds the median timesince-IPO of all public firms in the same calendar year), while column 2 restricts the sample of public firms to 'young' firms. Age for private firms is not available in Sageworks, so we continue to match on size and industry but not on age. Column 3 excludes private firms altogether and tests if the investment sensitivity of public firms depends on their age by interacting investment opportunities with log time since IPO. Column 4 includes public firms' R\&D spending in the dependent variable. Column 5 restricts the sample to $\mathrm{C}$ Corps in order to hold tax regime constant between public and private firms. Column 6 restricts the sample to firms using accrual-basis rather than cash accounting. In column 7 , we change the dependent variable from gross to net investment (i.e., the change in net fixed assets over beginning-of-year total assets). In column 8 , we test whether the results presented in Table 3, column 1 are robust to observable heterogeneity in cash holdings, book leverage, and firm size. For variable definitions and details of their construction, see Appendix A. Each regression includes firm fixed effects and year effects (not reported). Heteroskedasticity-consistent standard errors clustered at the firm level are shown in italics underneath the coefficient estimates. We use ${ }^{* * *},{ }^{* *}$, and ${ }^{*}$ to denote significance at the $1 \%, 5 \%$, and $10 \%$ level (two-sided), respectively. All continuous variables are winsorized $0.5 \%$ in each tail to reduce the impact of outliers.

\begin{tabular}{|c|c|c|c|c|c|c|c|c|}
\hline & \multicolumn{8}{|c|}{ Dependent variable: Investment / lagged total assets } \\
\hline & \multicolumn{3}{|c|}{ Lifecycle effects } & \multirow{2}{*}{$\begin{array}{l}\text { R\&D } \\
\text { effects, } \\
\text { matched } \\
\text { public } \\
\text { firms only } \\
\text { (4) }\end{array}$} & \multirow[b]{2}{*}{$\begin{array}{c}\text { Only C } \\
\text { Corps } \\
(5)\end{array}$} & \multirow{2}{*}{$\begin{array}{c}\text { Only } \\
\text { accrual } \\
\text { basis } \\
\text { accounting } \\
(6)\end{array}$} & \multirow[b]{2}{*}{$\begin{array}{c}\text { Net rather } \\
\text { than gross } \\
\text { investment } \\
\text { (7) }\end{array}$} & \multirow[b]{2}{*}{$\begin{array}{c}\text { Additiona } \\
\text { controls } \\
(8)\end{array}$} \\
\hline & $\begin{array}{c}\text { Old firms } \\
\text { (1) }\end{array}$ & $\begin{array}{c}\text { Young } \\
\text { firms } \\
(2)\end{array}$ & $\begin{array}{c}\text { Matched } \\
\text { public } \\
\text { firms only } \\
(3)\end{array}$ & & & & & \\
\hline Investment opportunities & $0.149^{* * *}$ & $0.131^{* * *}$ & $0.042^{*}$ & $0.042^{* * *}$ & $0.121^{* * *}$ & $0.131^{* * *}$ & $0.210^{* * *}$ & $0.092^{* * *}$ \\
\hline & 0.016 & 0.013 & 0.023 & 0.010 & 0.013 & 0.021 & 0.016 & 0.020 \\
\hline ... x public & $-0.095^{* * *}$ & $-0.096^{* * *}$ & & & $-0.085^{* * *}$ & $-0.092^{* * *}$ & $-0.175^{* * *}$ & $-0.058^{* * *}$ \\
\hline & 0.028 & 0.016 & & & 0.017 & 0.022 & 0.017 & 0.022 \\
\hline$\ldots x \ln (1+$ years since IPO $)$ & & & $\begin{array}{r}-0.002 \\
0.011\end{array}$ & & & & & \\
\hline ROA & $0.189^{* * *}$ & $0.169^{* * *}$ & $-0.134^{*}$ & $-0.123^{* *}$ & $0.159^{* * *}$ & $0.166^{* * *}$ & -0.006 & $0.174^{* * *}$ \\
\hline & 0.018 & 0.015 & 0.077 & 0.037 & 0.015 & 0.025 & 0.019 & 0.012 \\
\hline$\ldots \times$ public & $-0.121^{* *}$ & $-0.137^{* * *}$ & & & $-0.114^{* * *}$ & $-0.128^{* * *}$ & 0.007 & $-0.118^{* * *}$ \\
\hline$\ldots x \ln (1+$ years since IPO $)$ & 0.052 & 0.030 & $\begin{array}{l}0.076^{* *} \\
0.032\end{array}$ & & 0.032 & 0.034 & 0.028 & 0.030 \\
\hline Cash holdings & & & & & & & & $\begin{array}{l}0.116^{*} \\
0.065\end{array}$ \\
\hline Book leverage & & & & & & & & $\begin{array}{c}-0.157^{* *} \\
0.062\end{array}$ \\
\hline Size $(\ln$ (total assets) $)$ & & & & & & & & $\begin{array}{l}-0.055^{* * *} \\
0.017\end{array}$ \\
\hline$R^{2}$ (within) & $26.9 \%$ & $31.1 \%$ & $6.2 \%$ & $6.5 \%$ & $34.0 \%$ & $19.3 \%$ & $50.0 \%$ & $32.4 \%$ \\
\hline$F$-test: all coeff. $=0$ & $26.6^{* * *}$ & $24.7^{* * *}$ & $5.0^{* * *}$ & $5.7^{* * *}$ & $15.1^{* * *}$ & $11.0^{* * *}$ & $27.3^{* * *}$ & $80.1^{* * *}$ \\
\hline No. observations & 4,028 & 5,922 & 4,975 & 4,975 & 8,154 & 9,822 & 9,950 & 9,931 \\
\hline No. firms & 984 & 1,498 & 1,666 & 1,666 & 1,913 & 2,250 & 2,286 & 2,282 \\
\hline
\end{tabular}


Table 5. Arellano-Bond Estimates of Public and Private Firms’ Investment Sensitivities.

This table explores the robustness of the Table 3 results to potential measurement error in investment opportunities, using Arellano and Bond's (1991) one-step GMM estimator (or a variation thereof). We focus on our preferred specification, the matched sample of public and private firms with sales growth as the measure of investment opportunities. As in Table 3, we exploit within-firm variation. Specifically, we first-difference the data to remove firm fixed effects. For ease of comparison, column 1 reproduces the within-groups results from column 1 in Table 3 as a baseline. Columns 2 to 5 report the GMM results. In columns 2 and 3, we estimate two static GMM models. The first uses investment and sales growth dated $t-5$ to $t-3$ and year effects as instruments while the second adds ROA dated $t-5$ to $t-3$ to the instrument set. (Note that variables dated $t-2$ are mechanically correlated with the first-differences of sales growth and investment and so cannot be included in the instrument set.) Column 4 shows results from a system GMM model which jointly estimates a first-differenced equation as in columns 2 and 3 (instrumented with lagged variables in levels) and an equation in levels instrumented with lagged differences (see Blundell and Bond (1998)). This allows us to include a dummy for public firms and so to identify differences in investment levels between public and private firms. The specification in column 5 is dynamic and thus includes first lags of all variables in the estimated equation; however, for brevity, the table suppresses the coefficient estimates for all lags except for lagged investment. In the dynamic specification, only variables dated $t-5$ and $t-4$ can be used as instruments, which greatly affects identification as our panel is relatively short. For variable definitions and details of their construction, see Appendix A. Each regression includes an intercept and year effects (not reported). For the GMM models in columns 2 to 5, we report the $p$-values of the Hansen test of over-identification restrictions and the Arellano-Bond test for AR(3) in first differences. Heteroskedasticity-consistent standard errors clustered at the firm level are shown in italics underneath the coefficient estimates. We use ${ }^{* * *},{ }^{* *}$, and ${ }^{*}$ to denote significance at the $1 \%, 5 \%$, and $10 \%$ level (two-sided), respectively. All continuous variables are winsorized $0.5 \%$ in each tail to reduce the impact of outliers.

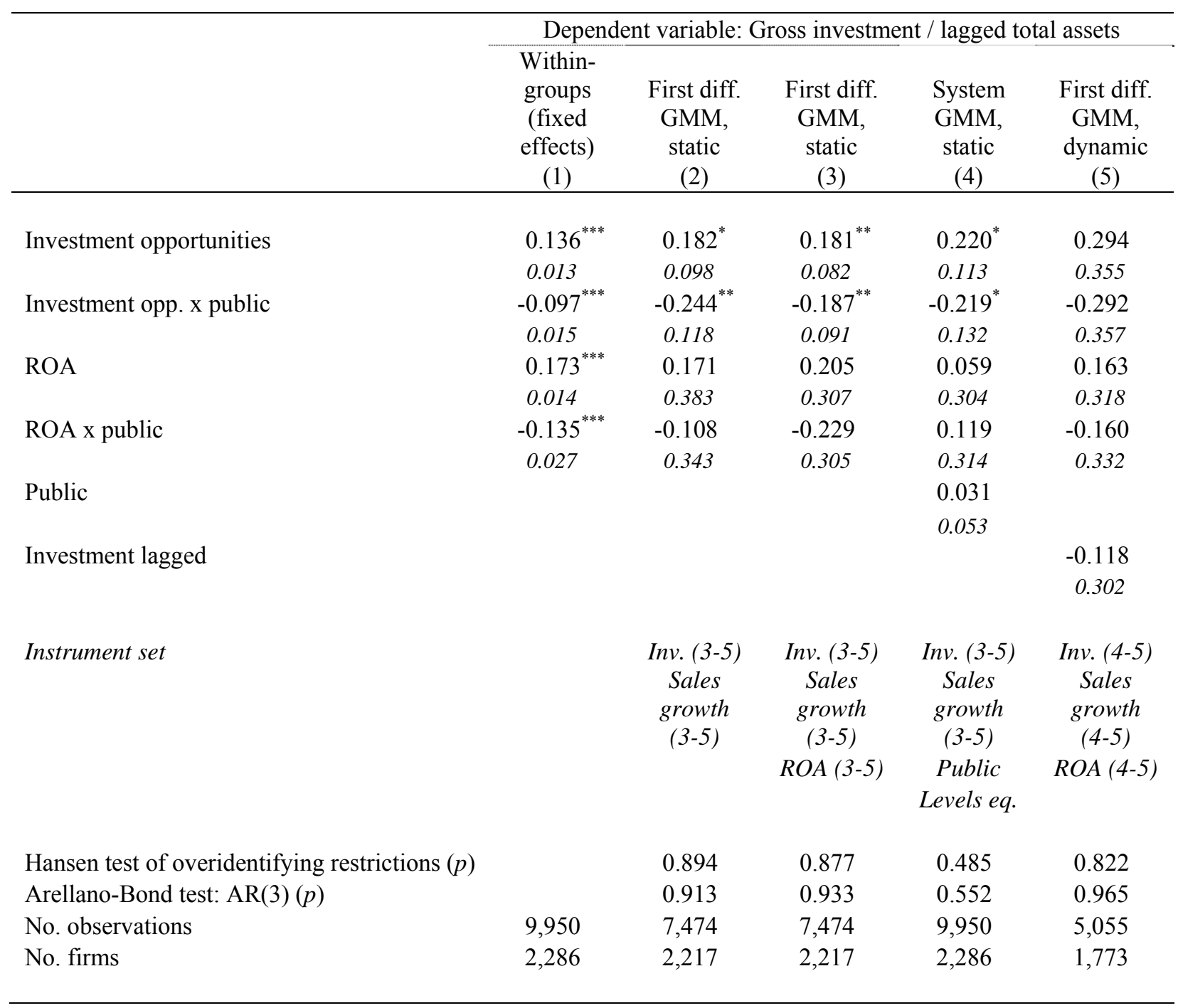


Table 6. Public and Private Firms' Reactions To State Corporate Income Tax Changes.

We use staggered changes in state corporate income taxes as plausibly exogenous shocks to investment opportunities. A firm is coded as experiencing a tax change if its headquarter state passed a tax cut or tax increase that became effective during the fiscal year in question. We hand-collect historic HQ states for Compustat firms as Compustat only reports current firm locations. Appendix B lists 33 tax changes in 19 states that occurred over the period 2001 through 2008 (one year either side of our sample period). Multi-state firms in column 4 are those listing operations in multiple states in Item 2 of their $10-\mathrm{K}$ filing for fiscal year $t-1$. The change in tax payments in column 5 is defined as $\operatorname{tax}_{t} /$ total assets $_{t}-\operatorname{tax}_{t-1} /$ total assets $_{t-1}$. In column 6 , we restrict the sample of private firms to the 20,448 firms (56,665 firm-years) that are non-C Corps (i.e., sole proprietorships, LLCs, partnerships, LLPs, and S Corps). Each regression includes firm fixed effects and year effects (not reported) and is estimated using leastsquares. Heteroskedasticity-consistent standard errors clustered at the firm level are shown in italics underneath the coefficient estimates. We use ${ }^{* * *},{ }^{* *}$, and ${ }^{*}$ to denote significance at the $1 \%, 5 \%$, and $10 \%$ level (two-sided), respectively. All continuous variables are winsorized $0.5 \%$ in each tail to reduce the impact of outliers.

\begin{tabular}{|c|c|c|c|c|c|c|}
\hline & \multicolumn{6}{|c|}{ Dependent variable: Gross investment / lagged total assets } \\
\hline & \multicolumn{5}{|c|}{$\begin{array}{c}\text { Matched sample } \\
\text { (No. observations }=9,950 ; \text { no. firms }=2,286)\end{array}$} & \multirow{2}{*}{$\begin{array}{c}\text { Private non-C } \\
\text { Corps } \\
(6)\end{array}$} \\
\hline & $(1)$ & $(2)$ & $(3)$ & $(4)$ & $(5)$ & \\
\hline \multirow[t]{2}{*}{ Tax change $($ cut $=1$, increase $=-1)$} & $0.072^{* * *}$ & & $0.091^{* * *}$ & $0.086^{* * *}$ & $0.072^{* * *}$ & 0.004 \\
\hline & 0.022 & & 0.020 & 0.026 & 0.022 & 0.005 \\
\hline \multirow[t]{2}{*}{$\mathrm{x}$ public } & $-0.056^{* *}$ & & $-0.069^{* * *}$ & & $-0.056^{* *}$ & \\
\hline & 0.025 & & 0.024 & & 0.025 & \\
\hline $\mathrm{x}$ public single-state firm & & & & $\begin{array}{l}-0.088^{* * *} \\
0.028\end{array}$ & & \\
\hline \multirow[t]{2}{*}{$\mathrm{x}$ public multi-state firm } & & & & $-0.072^{* * *}$ & & \\
\hline & & & & 0.028 & & \\
\hline \multirow[t]{2}{*}{ Tax cut } & & $0.092^{* * *}$ & & & & \\
\hline & & 0.033 & & & & \\
\hline \multirow[t]{2}{*}{$\mathrm{x}$ public } & & $-0.072^{*}$ & & & & \\
\hline & & 0.039 & & & & \\
\hline \multirow[t]{2}{*}{ Tax increase } & & $-0.053^{*}$ & & & & \\
\hline & & 0.028 & & & & \\
\hline \multirow[t]{2}{*}{ x public } & & 0.041 & & & & \\
\hline & & 0.030 & & & & \\
\hline \multirow[t]{2}{*}{ Tax change $(t-1)$} & & & 0.020 & & & \\
\hline & & & 0.013 & & & \\
\hline \multirow[t]{2}{*}{ x public } & & & -0.022 & & & \\
\hline & & & 0.016 & & & \\
\hline \multirow[t]{2}{*}{ Tax change $(t+1)$} & & & -0.034 & & & \\
\hline & & & 0.041 & & & \\
\hline \multirow[t]{2}{*}{ x public } & & & 0.001 & & & \\
\hline & & & 0.044 & & & \\
\hline \multirow{2}{*}{ Change in tax payments $t-1$ to $t$} & & & & & 0.036 & \\
\hline & & & & & 0.126 & \\
\hline \multirow[t]{2}{*}{$\mathrm{x}$ public } & & & & & 0.009 & \\
\hline & & & & & 0.144 & \\
\hline \multirow{2}{*}{ Sales growth } & $0.136^{* * *}$ & $0.136^{* * *}$ & $0.136^{* * *}$ & $0.136^{* * *}$ & $0.136^{* * *}$ & $0.053^{* * *}$ \\
\hline & 0.005 & 0.005 & 0.005 & 0.005 & 0.005 & 0.005 \\
\hline \multirow[t]{2}{*}{$\mathrm{x}$ public } & $-0.097^{* * *}$ & $-0.097^{* * *}$ & $-0.098^{* * *}$ & $-0.097^{* * *}$ & $-0.097^{* * *}$ & \\
\hline & 0.010 & 0.010 & 0.010 & 0.010 & 0.010 & \\
\hline \multirow[t]{2}{*}{ ROA } & $0.174^{* * *}$ & $0.174^{* * *}$ & $0.174^{* * *}$ & $0.174^{* * *}$ & $0.174^{* * *}$ & $0.037^{* * *}$ \\
\hline & 0.004 & 0.004 & 0.004 & 0.004 & 0.004 & 0.006 \\
\hline \multirow{2}{*}{$\mathrm{x}$ public } & $-0.135^{* * *}$ & $-0.135^{* * *}$ & $-0.135^{* * *}$ & $-0.135^{* * *}$ & $-0.135^{* * *}$ & \\
\hline & 0.024 & 0.024 & 0.024 & 0.024 & 0.024 & \\
\hline$R^{2}$ (within) & $29.8 \%$ & $29.8 \%$ & $29.8 \%$ & $29.8 \%$ & $29.8 \%$ & $3.5 \%$ \\
\hline$F$-test: all coefficients $=0 ?$ & $198.8^{* * *}$ & $169.7^{* * *}$ & $167.8^{* * *}$ & $182.1^{* * *}$ & $168.6^{* * *}$ & $33.5^{* * *}$ \\
\hline F-test: coeff.(tax change, public) $=0 ?$ & 1.7 & 1.1 & 2.3 & 0.7 & 1.7 & n.a. \\
\hline$F$-test: tax cut $=-$ tax increase? & n.a. & 0.5 & n.a. & n.a. & n.a. & n.a. \\
\hline F-test: single-state $=$ multi-state $?$ & n.a. & n.a. & n.a. & 0.8 & n.a. & n.a. \\
\hline
\end{tabular}


Table 7. Changes in Investment Sensitivities Around IPOs.

In this table, we estimate changes in the sensitivity of investment spending to investment opportunities around the IPOs of firms that go public for the sole purpose of allowing some of their existing shareholders to cash out. Appendix C lists their names, dates, and circumstances. We use sales growth as a measure of investment opportunities, given that this is the only measure available for pre-IPO observations. As in previous tables, we exploit within-firm variation by including firm fixed effects. Columns 1 and 2 report own-difference results for the IPO sample, where we interact investment opportunities and ROA with an indicator variable that equals one if the observation is post-IPO. Columns 3 and 4 report difference-in-difference results based on combining data from the IPO sample with data from a matched control sample of public firms. To be eligible for matching, a public firm must be in both Compustat and CRSP; be incorporated in the U.S. and listed on the NYSE, AMEX, or Nasdaq exchanges; have valid stock price data in CRSP; and have a CRSP share code no greater than 11. Each IPO firm is matched in its first sample year to up to five public firms in the same industry (three-digit SIC) with the closest total assets to the IPO firm in the year of the match. In three cases, this algorithm yields no eligible matches, so we broaden the industry criterion to two-digit SIC. On average, we have 3.7 matches per IPO firm. The difference-in-difference tests allow us to interact investment opportunities and ROA with separate indicators for pre- and post-IPO. Uncrossed variables capture the effect of investment opportunities and ROA on the investment decisions of the matched control public firms, while the interaction terms test whether IPO firms have investment behavior that is significantly different from that of their matched controls either before or after going public, respectively. We also allow for a level difference in investment spending between IPO and matched firms by including a post-IPO indicator. (Note that the presence of firm fixed effects rules out simultaneous inclusion of a pre-IPO indicator.) For variable definitions and details of their construction, see Appendix A. Each regression includes firm fixed effects and year effects (not reported for brevity) and is estimated using least-squares. Heteroskedasticity-consistent standard errors are shown in italics underneath the coefficient estimates. We use ${ }^{* * *},{ }^{* *}$, and ${ }^{*}$ to denote significance at the $1 \%, 5 \%$, and $10 \%$ level (two-sided), respectively. All continuous variables are winsorized $0.5 \%$ in each tail to reduce the impact of outliers.

\begin{tabular}{|c|c|c|c|c|}
\hline & \multicolumn{4}{|c|}{ Dependent variable: Investment / lagged total assets } \\
\hline & \multicolumn{2}{|c|}{ Own difference } & \multicolumn{2}{|c|}{$\begin{array}{l}\text { Diff-in-diff with matched } \\
\text { controls }\end{array}$} \\
\hline & $\begin{array}{c}\text { investment } \\
\text { (no R\&D) } \\
(1)\end{array}$ & $\begin{array}{l}\text { investment } \\
\text { (with } \\
\text { R\&D) } \\
(2)\end{array}$ & $\begin{array}{c}\text { investment } \\
\text { (no R\&D) } \\
(3)\end{array}$ & $\begin{array}{l}\text { investment } \\
\text { (with } \\
\text { R\&D) } \\
\text { (4) }\end{array}$ \\
\hline \multirow[t]{2}{*}{ Investment opportunities } & $0.074^{* * *}$ & $0.111^{* * *}$ & $0.013^{*}$ & $0.027^{* * *}$ \\
\hline & 0.025 & 0.031 & 0.007 & 0.008 \\
\hline \multirow[t]{2}{*}{ Investment opp. $\mathrm{x}$ pre-IPO } & & & $0.066^{* *}$ & $0.092^{* * *}$ \\
\hline & & & 0.028 & 0.035 \\
\hline \multirow[t]{2}{*}{ Investment opp. x post-IPO } & $-0.058^{*}$ & $-0.080^{*}$ & 0.003 & 0.006 \\
\hline & 0.032 & 0.041 & 0.020 & 0.027 \\
\hline \multirow[t]{2}{*}{$\mathrm{ROA}$} & 0.053 & 0.095 & $0.139^{* * *}$ & $0.140^{* * *}$ \\
\hline & 0.063 & 0.074 & 0.018 & 0.027 \\
\hline \multirow[t]{2}{*}{ ROA x pre-IPO } & & & -0.093 & -0.052 \\
\hline & & & 0.067 & 0.080 \\
\hline \multirow[t]{2}{*}{ ROA x post-IPO } & 0.059 & 0.057 & -0.019 & 0.019 \\
\hline & 0.053 & 0.062 & 0.038 & 0.046 \\
\hline \multirow[t]{2}{*}{ Post-IPO } & 0.001 & -0.004 & -0.004 & -0.006 \\
\hline & 0.010 & 0.012 & 0.009 & 0.012 \\
\hline$R^{2}$ (within) & $19.4 \%$ & $21.1 \%$ & $13.9 \%$ & $14.3 \%$ \\
\hline$F$-test: all coefficients $=0$ & $6.7^{* * *}$ & $7.3^{* * *}$ & $16.6^{* * *}$ & $14.8^{* * *}$ \\
\hline No. observations & 963 & 963 & 4,501 & 4,501 \\
\hline No. firms & 90 & 90 & 419 & 419 \\
\hline
\end{tabular}




\section{Table 8. Investment Sensitivities by Legal Form.}

This table tests whether private firms in our sample are likely to be free of agency problems that could distort their investment decisions. Agency problems ultimately stem from a separation of ownership and control and from dispersed ownership. Since Sageworks does not report ownership information, we use legal form as a proxy for ownership concentration instead. Sole proprietorships, LLCs (limited liability companies), partnerships, and limited liability partnerships (LLPs) in the U.S. are overwhelmingly owner-managed and have highly concentrated ownership (see Table A8 in the Online Data Appendix). The other two legal forms open to private firms - C Corps and S Corps - can theoretically have dispersed ownership. These account for the bulk of our sample firms. We test for differences in investment sensitivities between $\mathrm{C}$ and $\mathrm{S}$ Corps on the one hand and the other types of private firms in our sample on the other. If the private $\mathrm{C}$ and $\mathrm{S}$ Corps in our sample were to have dispersed ownership and thus suffer from agency problems, their investment behavior should be systematically different from that of the other types of private sample firms. Column 1 includes all private sample firms and allows investment sensitivities to vary by legal form. The null is that the investment sensitivities do not differ by legal form, which we test with a Wald test. The uninteracted effect in column 1 captures the investment sensitivity of C Corps (together with 702 firms of unknown legal origin; dropping these has no bearing on the results). Columns 2 and 3 focus on sole proprietorships which, by definition, have a single owner. In column 2, we compare the investment behavior of sole proprietorships to that of all other private firms, while in column 3 we match each sole proprietorship by size and industry to a private firm that is not a sole proprietorship, using the same matching algorithm described in Section 2.2. In columns 4 and 5, we group sole proprietorships with LLCs, partnerships, and LLPs and compare this group to $\mathrm{C}$ and $\mathrm{S}$ Corps, using either the entire sample (column 4 ) or a size-and-industry matched sample (column 5). Each regression includes firm fixed effects and year effects (not reported) and is estimated using least-squares. Heteroskedasticity-consistent standard errors clustered at the firm level are shown in italics underneath the coefficient estimates. We use ${ }^{* * *},{ }^{* *}$, and ${ }^{*}$ to denote significance at the $1 \%, 5 \%$, and $10 \%$ level (two-sided), respectively. All continuous variables are winsorized $0.5 \%$ in each tail to reduce the impact of outliers.

\begin{tabular}{|c|c|c|c|c|c|}
\hline & \multicolumn{5}{|c|}{ Dependent variable: Gross investment / lagged total assets } \\
\hline & & \multicolumn{2}{|c|}{ Sole proprietorships } & \multicolumn{2}{|c|}{$\begin{array}{l}\text { Sole prop. + LLC + } \\
\text { partnership + LLP }\end{array}$} \\
\hline & $\begin{array}{c}\text { All private } \\
\text { firms } \\
(1) \\
\end{array}$ & $\begin{array}{l}\text { vs. all other } \\
\text { private } \\
\text { firms } \\
(2)\end{array}$ & $\begin{array}{l}\text { matched to } \\
\text { similar } \\
\text { private } \\
\text { firms } \\
(3)\end{array}$ & $\begin{array}{l}\text { vs. all other } \\
\text { private } \\
\text { firms } \\
(4) \\
\end{array}$ & $\begin{array}{l}\text { matched to } \\
\text { similar } \\
\text { private } \\
\text { firms } \\
(5)\end{array}$ \\
\hline Investment opportunities & $0.057^{* * *}$ & $0.054^{* * *}$ & $0.106^{* * *}$ & $0.054^{* * *}$ & $0.073^{* * *}$ \\
\hline & 0.007 & 0.004 & 0.036 & 0.004 & 0.018 \\
\hline $\mathrm{x}$ sole proprietorship & -0.017 & -0.020 & -0.065 & & \\
\hline & 0.041 & 0.043 & 0.057 & & \\
\hline $\mathrm{x}$ LLC & $\begin{array}{r}-0.003 \\
0.013\end{array}$ & & & & \\
\hline x partnership & $\begin{array}{r}-0.013 \\
0.016\end{array}$ & & & & \\
\hline $\mathrm{x}$ LLP & $\begin{array}{r}-0.035 \\
0.024\end{array}$ & & & & \\
\hline x S Corp & $\begin{array}{r}-0.003 \\
0.009\end{array}$ & & & & \\
\hline $\mathrm{x}$ (sole prop. + LLC + partnership + LLP) & & & & $\begin{array}{r}-0.005 \\
0.010\end{array}$ & $\begin{array}{c}-0.026 \\
0.019\end{array}$ \\
\hline ROA & $0.034^{* * *}$ & $0.033^{* * *}$ & $0.078^{* *}$ & $0.034^{* * *}$ & $0.050^{* * *}$ \\
\hline x sole proprietorship & 0.005 & $\begin{array}{l}0.005 \\
0.023 \\
0.028\end{array}$ & $\begin{array}{c}0.032 \\
-0.024 \\
0.043\end{array}$ & 0.005 & 0.018 \\
\hline $\mathrm{x}$ (sole prop. + LLC + partnership + LLP) & & & & $\begin{array}{r}-0.005 \\
0.015\end{array}$ & $\begin{array}{c}-0.023 \\
0.023\end{array}$ \\
\hline$R^{2}$ (within) & $3.2 \%$ & $3.2 \%$ & $6.0 \%$ & $3.2 \%$ & $3.7 \%$ \\
\hline$F$-test: all coeff. $=0$ & $29.4^{* * *}$ & $39.2^{* * *}$ & $4.6^{* * *}$ & $39.0^{* * *}$ & $10.6^{* * *}$ \\
\hline F-test: inv. opp. interaction coefficients $=0$ & 0.54 & n.a. & n.a. & n.a. & n.a. \\
\hline No. observations & 88,568 & 88,568 & 2,530 & 88,568 & 19,244 \\
\hline No. firms & 32,204 & 32,204 & 1,168 & 32,204 & 8,058 \\
\hline
\end{tabular}




\section{Table 9. Cross-industry Variation in Short-termism.}

Short-termism models predict that the difference in investment sensitivities between public and private firms is zero for $\alpha_{0}=0$ and then increases in $\alpha_{0}$, where $\alpha_{0}$ measures how sensitive a public firm's stock price is to its current cash flows. We follow the accounting literature and use the earnings response coefficient (ERC) to capture a firm's stock price sensitivity and include a full set of interaction terms involving ERC in our baseline investment equation from Table 3. For details of how we construct ERC, see Appendix A. Pane A shows the results, using our matched sample of private and public firms. We report results for two separate measures of ERC, estimated at the Fama-French (1997) 30 industry level (row 1) and at the Fama-French 48 industry level (row 2). As before, the dependent variable is gross investment over lagged assets and the regression includes firm fixed effects and year effects (not reported) and is estimated using least-squares. Panel B illustrates the effect of ERC on investment sensitivities, as estimated in Panel A, for private and public firms at the $25^{\text {th }}$ and $75^{\text {th }}$ percentile of the ERC distribution $(0.077$ and 0.289 , respectively, when using Fama-French 30 industries and 0.085 and 0.323 , respectively, when using Fama-French 48 industries). In Panel C, we test the follow-on prediction that public firms account for a smaller share of activity in an industry the higher is the industry's ERC. The unit of observation is a four-digit NAICS industry. We exclude government entities (NAICS 92XX, 5211, 4911, and 8131), pension funds (5251), REITs and other investment trusts (5259), and private households (8141). Data availability restricts us to a single cross-section, for 2007. The independent variables besides the industry's ERC are the industry's R\&D intensity and its capital intensity. For details of their construction, see Appendix A. In column 1 of Panel C, the dependent variable is the ratio of the number of public firms in an industry. Specifically, we divide the number of firms in Compustat during fiscal year 2007 that belong to a particular NAICS4 industry by the total number of firms (public + private) active in that industry according to the 2007 "Statistics of U.S. Businesses" provided by the Census Bureau. We require that Compustat firms are located in the U.S. (excluding Puerto Rico and the U.S. Virgin Islands), are listed on a major exchange, have a price quote in CRSP, have a CRSP share code no greater than 11, and report positive sales. This variable ignores differences in firm size and so can produce meaningless results. For example, if a public firm produces $99 \%$ of the output in an industry but there are thousands of tiny private firms, the industry would still be classified as being dominated by private firms. Chod and Lyandes (2010) suggest limiting the denominator (the total number of firms) to firms of a certain size (e.g., in terms of employment). We follow their approach and report results for firms with at least 100 employees (column 2) or at least 500 employees (column 3). Since we model fractions, Panel C is estimated using standard fractional logits (results are similar using OLS). Heteroskedasticity-consistent standard errors are shown in italics. In Panels A and B, they are clustered at the firm level. In Panel C, where the unit of observation is a four-digit NAICS industry, they are clustered at the Fama-French-30 industry level, the level at which ERC is measured. This is more conservative than clustering at the NAICS4 level. We use , , and to denote significance at the 1\%, 5\%, and 10\% level (two-sided), respectively. In Panel C, we report marginal effects in brackets underneath the standard errors. They are computed for a one-standard deviation increase in the relevant variable, holding the other covariates constant, and should be compared to the sample mean of the dependent variable, reported in the last row of Panel C. The number of firm-years in Panels A and B is 9,950 and the number of firms is 2,286. The number of NAICS4 industries in Panel C is 283 . In Panel A, all continuous variables are winsorized $0.5 \%$ in each tail to reduce the impact of outliers.

\section{Panel A: Interaction results}

\begin{tabular}{|c|c|c|c|c|c|c|c|c|c|c|c|}
\hline Row & Industry definition & $\begin{array}{c}\text { Sales } \\
\text { growth }\end{array}$ & $\begin{array}{c}\text { Sales } \\
\text { growth } \mathrm{x} \\
\text { public }\end{array}$ & $\begin{array}{c}\text { Sales } \\
\text { growth } \mathrm{x} \\
\text { ERC } \\
\end{array}$ & $\begin{array}{c}\text { Sales } \\
\text { growth x } \\
\text { ERC x } \\
\text { public }\end{array}$ & ERC & $\begin{array}{l}\text { ERC x } \\
\text { public }\end{array}$ & ROA & $\begin{array}{l}\text { ROA x } \\
\text { public }\end{array}$ & $\begin{array}{c}R^{2} \\
\text { (within) } \\
\end{array}$ & $\begin{array}{c}F \text {-test: } \\
\text { all coef. } \\
=0\end{array}$ \\
\hline 1 & Fama-French 30 industries & $\begin{array}{l}0.099^{* * *} \\
0.031\end{array}$ & $\begin{array}{c}-0.033 \\
0.036\end{array}$ & $\begin{array}{l}0.208 \\
0.154\end{array}$ & $\begin{array}{c}-0.373^{* *} \\
0.174\end{array}$ & $\begin{array}{l}0.017 \\
0.058\end{array}$ & $\begin{array}{c}-0.010 \\
0.057\end{array}$ & $\begin{array}{l}0.168^{* * *} \\
0.019\end{array}$ & $\begin{array}{c}-0.139^{* * *} \\
0.028\end{array}$ & $30.6 \%$ & $13.1^{* * *}$ \\
\hline 2 & Fama-French 48 industries & $\begin{array}{l}0.106^{* * *} \\
0.028\end{array}$ & $\begin{array}{c}-0.048 \\
0.032\end{array}$ & $\begin{array}{l}0.189 \\
0.157\end{array}$ & $\begin{array}{c}-0.298^{*} \\
0.166\end{array}$ & $\begin{array}{l}0.082 \\
0.053\end{array}$ & $\begin{array}{c}-0.064 \\
0.056\end{array}$ & $\begin{array}{l}0.167^{* * *} \\
0.019\end{array}$ & $\begin{array}{c}-0.135^{* * *} \\
0.028\end{array}$ & $30.6 \%$ & $14.1^{* * *}$ \\
\hline
\end{tabular}




\section{Panel B: Implied investment sensitivities}

\begin{tabular}{|c|c|c|c|c|c|c|}
\hline & \multicolumn{2}{|c|}{$\begin{array}{c}\text { Low ERC } \\
\text { (25th percentile) }\end{array}$} & \multicolumn{2}{|c|}{$\begin{array}{c}\text { High ERC } \\
\text { (75th percentile) }\end{array}$} & \multicolumn{2}{|c|}{ Difference } \\
\hline & coeff. & std. error & coeff. & std. error & coeff. & std. error \\
\hline \multicolumn{7}{|c|}{ Fama-French 30 industries: } \\
\hline Private firms & $0.115^{* * *}$ & 0.021 & $0.160^{* * *}$ & 0.023 & 0.044 & 0.033 \\
\hline Public firms & $0.054^{* * *}$ & 0.013 & $0.019^{*}$ & 0.010 & $-0.035^{* *}$ & 0.017 \\
\hline Difference & $0.062^{* * *}$ & 0.025 & $0.141^{* * *}$ & 0.025 & $0.079^{* *}$ & 0.037 \\
\hline \multicolumn{7}{|c|}{ Fama-French 48 industries: } \\
\hline Private firms & $0.122^{* * *}$ & 0.018 & $0.167^{* * *}$ & 0.030 & 0.045 & 0.037 \\
\hline Public firms & $0.049^{* * *}$ & 0.012 & $0.023^{* *}$ & 0.009 & $-0.026^{*}$ & 0.013 \\
\hline Difference & $0.073^{* * *}$ & 0.021 & $0.144^{* * *}$ & 0.031 & $0.071^{*}$ & 0.039 \\
\hline
\end{tabular}

\section{Panel C: Public firms' industry shares and ERC}

\begin{tabular}{|c|c|c|c|}
\hline & \multicolumn{3}{|c|}{$\begin{array}{l}\text { Fraction of firms in a four-digit NAICS } \\
\text { industry that are public, measured by the } \\
\text { number of firms }\end{array}$} \\
\hline & $\begin{array}{l}\text { all firms } \\
\text { (1) }\end{array}$ & $\begin{array}{c}\text { with } 100 \text { or } \\
\text { more } \\
\text { employees } \\
(2)\end{array}$ & $\begin{array}{c}\text { with } 500 \text { or } \\
\text { more } \\
\text { employees } \\
(3)\end{array}$ \\
\hline \multirow[t]{3}{*}{ ERC } & $-4.408^{* *}$ & $-5.271^{* * *}$ & $-5.110^{* * *}$ \\
\hline & 1.865 & 1.661 & 1.960 \\
\hline & {$[-0.001]$} & {$[-0.015]$} & {$[-0.033]$} \\
\hline \multirow[t]{3}{*}{ industry R\&D intensity } & $15.916^{* * *}$ & $20.625^{* * *}$ & $26.348^{* * *}$ \\
\hline & 1.611 & 2.846 & 4.361 \\
\hline & {$[0.001]$} & {$[0.017]$} & {$[0.048]$} \\
\hline \multirow[t]{3}{*}{ industry capital intensity } & $6.800^{* * *}$ & $4.607^{* * *}$ & $4.334^{* * *}$ \\
\hline & 1.858 & 1.236 & 1.156 \\
\hline & {$[0.003]$} & {$[0.018]$} & {$[0.038]$} \\
\hline$R^{2}$ & $62.1 \%$ & $40.6 \%$ & $30.3 \%$ \\
\hline Sample mean of dep. var. & 0.006 & 0.046 & 0.099 \\
\hline
\end{tabular}

